\title{
Neuroendocrine tumours: cracking the epigenetic code
}

\author{
A Karpathakis ${ }^{1,2}$, H Dibra ${ }^{1}$ and C Thirlwell ${ }^{1,2}$ \\ ${ }^{1}$ University College London Cancer Institute, 72 Huntley Street, London WC1E 6BT, UK ${ }^{2}$ Neuroendocrine Tumour \\ Unit, Royal Free Hospital, Pond Street, London NW3 2QG, UK
}

Correspondence

should be addressed

to C Thirlwell

Email

christina.thirlwell@ucl.ac.uk

\begin{abstract}
The field of epigenetics has evolved rapidly over recent years providing insight into the tumorigenesis of many solid and haematological malignancies. Determination of epigenetic modifications in neuroendocrine tumour (NET) development is imperative if we are to improve our understanding of the biology of this heterogenous group of tumours. Epigenetic marks such as DNA methylation at RASSF1A are frequent findings in NETs of all origins and may be associated with worse prognosis. MicroRNA signatures and histone modifications have been identified which can differentiate subtypes of NET and distinguish NET from adenocarcinoma in cases of diagnostic uncertainty. Historically, candidate genedriven approaches have yielded limited insight into the epigenetics of NET. Recent progress has been facilitated by development of high-throughput tools including second-generation sequencing and arrays for analysis of the 'epigenome' of tumour and normal tissue, permitting unbiased approaches such as exome sequencing that identified mutations of chromatin-remodelling genes ATRXIDAXX in $44 \%$ of pancreatic NETs. Epigenetic changes are reversible and therefore represent an attractive therapeutic target; to date, clinical outcomes of epigenetic therapies in solid tumours have been disappointing; however, in vitro studies on NETs are promising and further clinical trials are required to determine utility of this class of novel agents. In this review, we perform a comprehensive evaluation of epigenetic changes found in NETs to date, including rare NETs such as phaeochromocytoma and adrenocortical tumours. We suggest priorities for future research and discuss potential clinical applications and novel therapies.
\end{abstract}

\author{
Key Words \\ - Neuroendocrine \\ - epigenetic, methylation \\ - histone \\ - miRnA \\ - carcinoid \\ - RASSF1 \\ - ATRXIDAXX
}

Endocrine-Related Cancer (2013) 20, R65-R82

\section{Introduction}

Epigenetics can be defined as the study of heritable changes in gene expression without alteration of the underlying DNA sequence. In recent years, the understanding of epigenetic drivers of tumorigenesis has developed rapidly in part due to improvements in sequencing technology. While the study of genetics mutations, deletions and alterations to DNA - has led to many significant breakthroughs in medicine, it is increasingly apparent that for many human diseases epigenetic drivers are key to pathogenesis and may have significant impact on clinical practice and patient management. Integration of genetics, epigenetics and gene expression can generate a holistic understanding of the molecular basis of malignancy. The recent discovery of mutations in the novel tumour suppressor genes and chromatin remodellers $A T R X / D A X X$ through exome sequencing represent significant progress in our understanding of neuroendocrine tumour (NET) development.

Published by Bioscientifica Ltd. 
NETs are a heterogenous group of tumours, which until recently have remained largely intractable to genetic characterisation, with many research studies being performed with a small number of samples leading to the identification of low-frequency mutations, which do not appear to have significant prognostic or therapeutic impact. There is significance to the many negative findings in the research of NET genetics: classical tumour suppressor and oncogenes implicated in the development of many solid tumours do not appear to play a significant role in NET pathogenesis (for example P53 (TP53), RB (RB1) and KRAS are only very infrequently mutated or deleted in NET), suggesting the presence of alternative pathogenic drivers (Yoshimoto et al. 1992, Yashiro et al. 1993, Chung et al. 1997a).

Here, we provide a review into the current knowledge of epigenetic changes in NET to facilitate further research and identification of potential epigenetic drivers of NET tumorigenesis and identify novel biomarkers.

\section{Epigenetic modifications}

DNA methylation is the best-understood and most stable epigenetic mark; it occurs primarily at the $5^{\prime}$-position of the cytosine ring within $\mathrm{CpG}$ dinucleotides. $\mathrm{CpG}$ sites are clustered in 'islands' in the promoter region of up to $70 \%$ of genes, and methylation is facilitated by DNA methyltransferase enzymes (DNMTs). Three families of DNMT have been identified: DNMT1, which maintains methylation, DNMT2, whose specific role is unknown, and DNMT3, which functions as a de novo methyltransferase (Bestor 1992, Okano et al. 1998a,b, 1999). Recent identification of conversion of 5-methylcytosine to 5-hydroxymethylcytosine by the TET group of enzymes provides further insight into the complexities of regulating gene expression, but this has not yet been investigated in NET (Tahiliani et al. 2009). Patterns of DNA methylation are tissue specific; therefore, comparisons of tumour and normal tissue methylation must be carefully matched to reduce artefactual results.

Histones are the primary component of chromatin and function to package DNA into nucleosomes. Posttranslational covalent histone modifications regulate accessibility of genes to transcription factors by formation of binary states either 'permissive/open' or 'repressive/ closed', and the establishment and maintenance of chromatin structure help to maintain cellular identity through repression of non-essential genes (Chi \& Bernstein 2009). Histone modifications include acetylation, methylation and phosphorylation; these are catalysed by several enzymes, for example histone acetyltransferases and deacetylases (HDACs).

MicroRNAs (miRNAs) are small single-stranded RNA molecules of $\sim 22$ nucleotides in length, which posttranscriptionally regulate gene expression. Over the past decade, there has been a growing interest in miRNA and their involvement in the contribution of the development of cancer, and it has been recently shown that miRNA profiling can classify human cancers (Lu et al. 2005). Figure 1 illustrates the primary mechanisms of epigenetic alteration. These processes work synergistically to modify gene expression and determine cellular phenotype, in particular the maintenance of the differentiated cellular state. Influence from environmental factors such as diet and smoking is known to affect epigenetic status and is likely to play a significant role in tumorigenesis (Feil \& Fraga 2011).

\section{Key epigenetic findings in cancer}

Epigenetic changes are known to play a fundamental role in cancer development (Jones \& Baylin 2002, Jones \& Martienssen 2005). Early research identifying global hypomethylation of tumours relative to normal tissue demonstrated one of the first documented epigenetic alterations in human cancer cell lines in 1983 (Feinberg \& Vogelstein 1983). Global hypomethylation increases during tumour development (Fraga et al. 2004) and is believed to contribute to chromosomal instability (Eden et al. 2003). Hypermethylation of CpG islands in the promoter regions of tumour suppressor genes has been recognised as an early event in many cancers including retinoblastoma (Greger et al. 1989, Sakai et al. 1991). Promoter hypermethylation has subsequently been identified at sites such as VHL, BRCA, RASSF1A and p16INK4a (CDKN2A) where associated loss of expression is seen (Herman et al. 1994, Merlo et al. 1995, Catteau et al. 1999, Dammann et al. 2000). Next-generation sequencing permits definition of full tumour 'methylomes' at singlenucleotide resolution, and there are currently large-scale international collaborative studies underway that will provide freely available epigenetic data for normal and tumour tissues; although due to their relative rarity, NETs are not included in most of these projects (The American Association for Cancer Research Human Epigenome Task Force \& European Union 2008, Chadwick 2012).

Histone modifications also contribute to tumorigenesis, for example global reduction of acetylation at Lys16 (H4K16Ac) and of trimethylation at Lys20 of histone $\mathrm{H} 4$ (H4K20me3) is observed in several cancers (Fraga et al. 2005). Dimethylation of histone H3 at lysine 4

Published by Bioscientifica Ltd 


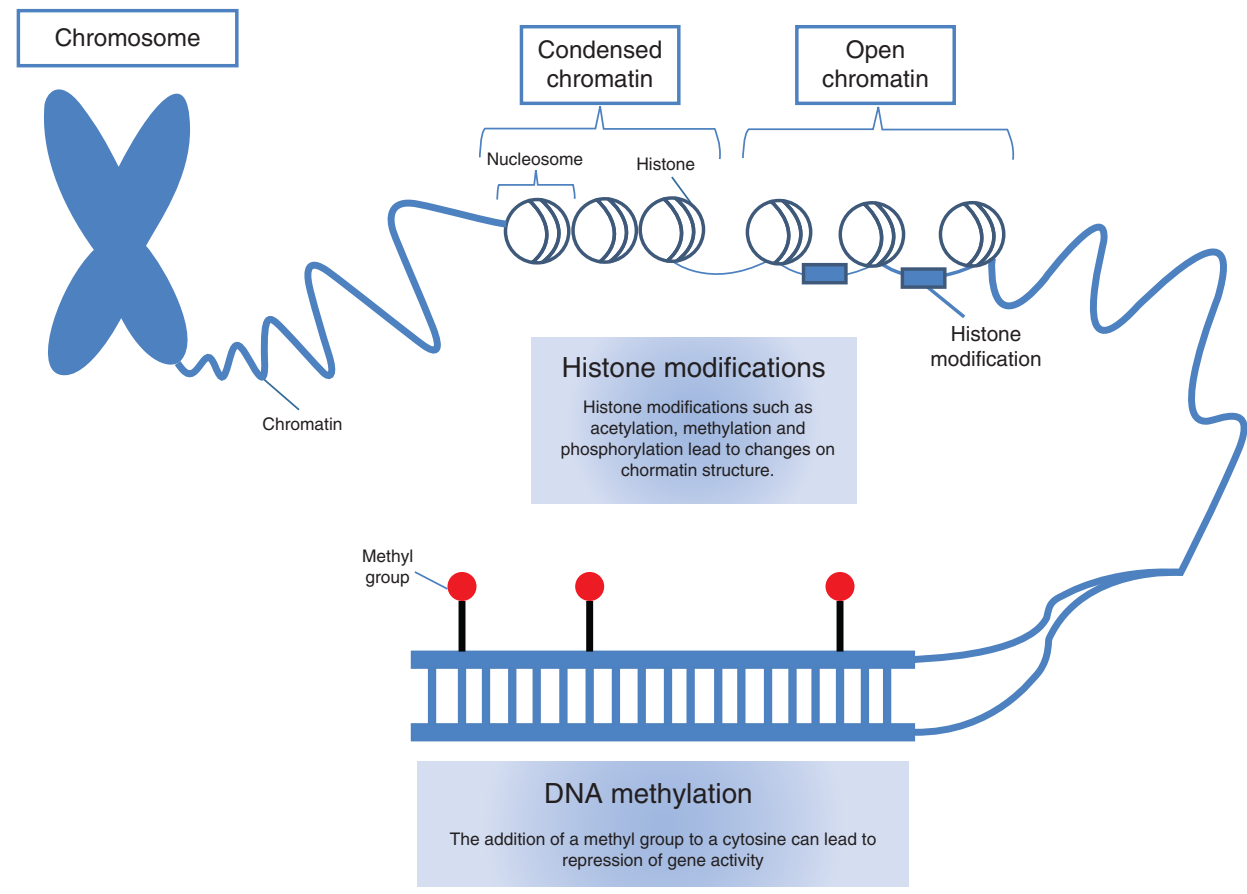

Figure 1

Mechanisms of histone modification and DNA methylation in human tissues.

(H3K4diMe) has been shown to be associated with an activated transcriptional state and is predictive of outcome in prostate and lung cancer (Seligson et al. 2005, Barlesi et al. 2007).

Epigenetic aberrations often preceded 'classical' genetic changes found in cancer such as tumour suppressor gene mutation, proto-oncogene activation and genomic instability and could therefore be utilised as early biomarkers. Hypermethylation of glutathione $S$ transferase (GSTP1) is a highly specific diagnostic biomarker in prostate cancer detectable in blood and urine (Cairns et al. 2001) and hypermethylation of the DNA repair gene $M G M T$ is a predictive biomarker of response to temozolomide (Hegi et al. 2005). There are few studies that have specifically investigated miRNA expression in NETs; although in other tumour types, miRNA signatures show utility as diagnostic and predictive biomarkers (Liu et al. 2012, Wang et al. 2012).

A key element driving therapeutic approaches to epigenetic modifications is the reversibility of DNA methylation and histone marks - this has been exploited successfully through histone deacetylase inhibitors (HDACi) and DNA demethylators. Two agents, 5-azacytidine and 5-aza-2'-deoxycytidine (decitabine), have been approved for treatment of myelodysplastic syndrome and leukaemia respectively (Muller et al. 2006,
Oki et al. 2007). In ovarian cancer, demethylating agents have been shown to cause resensitisation to platinum in heavily pretreated populations resulting in response rates of up to 35\% and progression-free survival of 5.6-10.2 months (Fu et al. 2011, Matei et al. 2012). However, other early phase trials in solid tumours have been largely disappointing, and to date, there have been no clinical trials of these two agents in NET patients. Figure 2 provides a timeline of key developments in the field of epigenetics, alongside key NET research findings.

\section{Pancreatic NETs}

Pancreatic NETs (pNETs) comprise functioning tumours (40-55\%) including gastrinoma, insulinoma, VIPoma and glucagonoma as well as non-functional NETs. Overall 5-year survival for pNET is $80 \%$ for all stages and $25 \%$ for metastatic disease; median survival is only 10 months for high-grade/poorly differentiated tumours. Improvements in prognostication and personalisation of treatment are required in order to improve patient outcomes. PNETs are perhaps the best-characterised group of NET, but despite this, reports of frequency of epigenetic marks vary significantly between studies and will require stringent validation before clinical applications can be developed. Insulinomas display more indolent clinical behaviour

Published by Bioscientifica Ltd. 


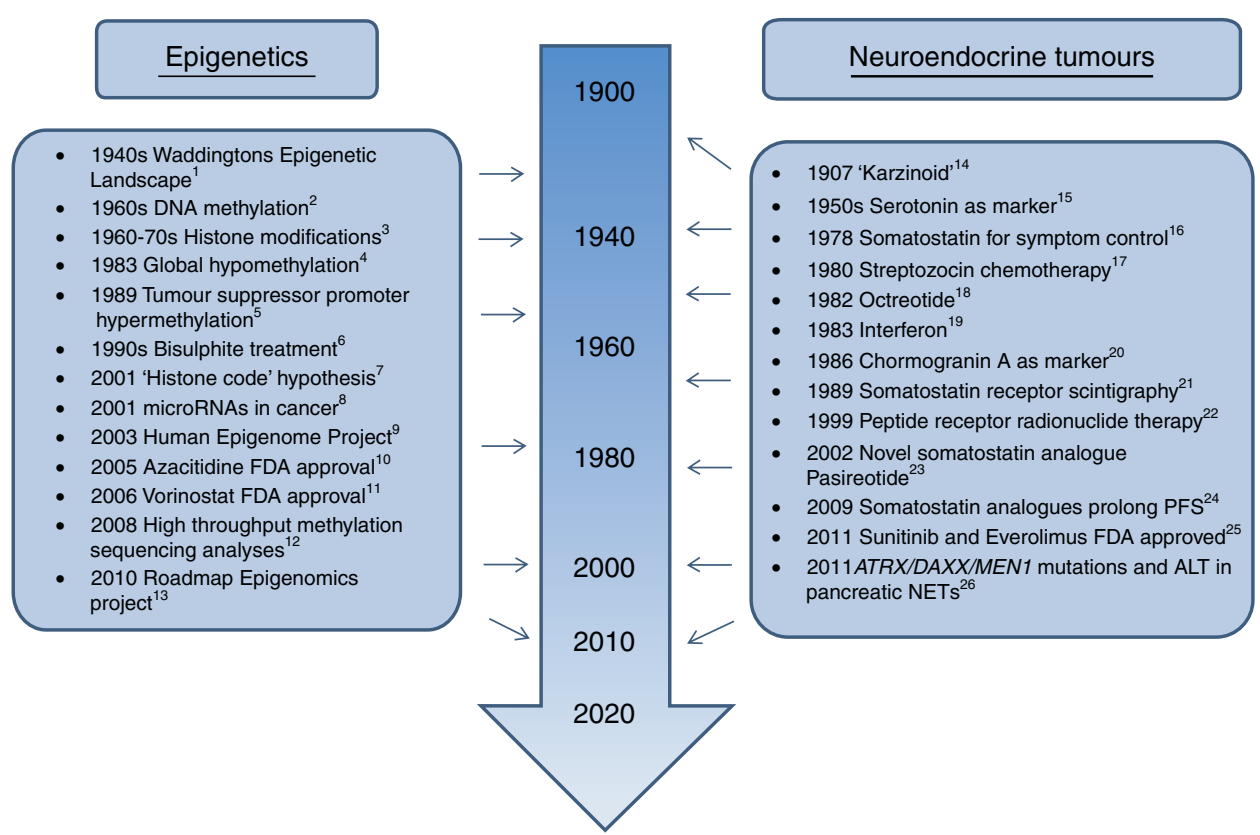

Figure 2

Timeline of key developments in epigenetic research and neuroendocrine tumour research and treatment advances. Figure 2 references: ${ }^{1}($ Waddington 1957), ${ }^{2}$ (Friedman et al. 1963), ${ }^{3}$ (Allfrey et al. 1964), ${ }^{4}$ (Feinberg \& Vogelstein 1983), ${ }^{5}$ (Greger et al. 1989, Sakai et al. 1991), ${ }^{6}$ (Clark et al. 1994), ${ }^{7}$ (Jenuwein \& Allis 2001), ${ }^{8}$ (Lagos-Quintana et al. 2001, Calin et al. 2004), ${ }^{9}$ (Eckhardt et al. 2004), ${ }^{10}$ (Kaminskas et al. 2005), ${ }^{11}$ (Mann et al. 2007), ${ }^{12}$ (Lister et al. 2008), ${ }^{13}$ (Bernstein et al. 2010), ${ }^{14}$ (Modlin et al. 2004), ${ }^{15}$ (Lembeck 1954, Pernow \& Waldenstrom 1954), ${ }^{16}$ (Frolich et al. 1978), ${ }^{17}$ (Moertel et al. 1980), ${ }^{18}$ (Bauer et al. 1982), ${ }^{19}$ (Oberg et al. 1983), ${ }^{20}$ (O'Connor \& Deftos 1986), ${ }^{21}$ (Krenning et al. 1989), ${ }^{22}$ (Krenning et al. 1999), ${ }^{23}$ (Bruns et al. 2002), ${ }^{24}$ (Rinke et al. 2009),

${ }^{25}$ (Raymond et al. 2011, Yao et al. 2011), ${ }^{26}$ (Jiao et al. 2011).

than other pNETs, and this is reflected in the emergence of distinct epigenetic patterns in this class of tumours.

\section{DNA methylation in PNET}

\section{RASSF1A promoter region is frequently hypermethylated in pNET}

The Ras-association domain gene family 1 (RASSF 1 ) tumour suppressor gene acts to induce cell cycle arrest and is inactivated in a wide variety of human cancers, usually as a result of epigenetic promoter methylation, somatic mutations of the gene bring extremely rare (Shivakumar et al. 2002, Dammann et al. 2003b). Different isoforms of RASSF1 exist and are associated with distinct promoter regions and alternative splicing. Within this review, we cite RASSF1 as described in the original research articles.

The largest study of DNA methylation in NETs included 48 largely non-functional (94\%) pNETs, which were analysed for methylation of the promoter region of 11 candidate tumour suppressor genes. The most commonly hypermethylated promoter region was that of
RASSF1A (75\%), which was unmethylated in the adjacent normal tissue. Fourteen cases had synchronous hepatic metastases, the majority of which demonstrated identical methylation status as the primary tumour (House et al. 2003). Separate studies have identified RASSF 1 promoter methylation in $80-83 \%$ of pNETs making it the most frequently altered gene in sporadic pNET identified to date. In some cases, methylation is also identified in matched normal pancreas, however at a lower level of expression (Dammann et al. 2003a, Malpeli et al. 2011). RASSF1 methylation has been noted to be more frequent in metastatic tumours (100\%) than non-metastatic (71\%) (Malpeli et al. 2011). Methylation of the RASSF1 promoter occurs less frequently in pancreatic ductal adenocarcinoma (Dammann et al. 2003a).

In contrast to RASSF1A, the RASSF $1 C$ isoform expression is 11.4 times higher in pNET than in normal tissue $(P=0.001)$ (Malpeli et al. 2011). RASSF1C has been shown to have a role inhibiting $\beta$-catenin degradation and given the above findings may also have a pathogenic role in pNET development (Estrabaud et al. 2007). RASSF1B is ubiquitously expressed in both tumour and normal tissue (Toyota et al. 1999).

Published by Bioscientifica Ltd. 
CDKN2A promoter methylation distinguishes subtypes of PNET and may be prognostic

Cyclin-dependent kinase inhibitor $2 \mathrm{a} / \mathrm{P} 16 \mathrm{INK} 4 \mathrm{a}$ is a tumour suppressor gene that plays a vital role in cell cycle regulation. Loss of heterozygosity on chromosome 9p21 (where P16/CDKN2A is located) is one of the most frequent genetic alterations in human cancer, and promoter methylation at this site is a common feature of many malignancies including breast (33\%), prostate (60\%) and colorectal cancer (92\%) (Herman et al. 1995).

Methylation at the CDKN2A/P16 locus has been demonstrated in QGP1 (a pNET cell line) (Lubomierski et al. 2001) and in $40 \%$ of pNETs (associated with early tumour recurrence and reduced overall survival) (House et al. 2003). Unlike RASSF1, methylation of CDKN2A/ p16INK4a is less frequent in pNET than in adenocarcinoma (Dammann et al. 2003a). In two studies of gastrinomas, hypermethylation of the CDKN2A/p16INK $4 a$ promoter has been found in $52-62.5 \%$ of cases independent of disease stage, location of primary or prognosis, suggesting that methylation of the CDKN2A/p16INK4a promoter may be an early occurrence in gastrinoma tumorigenesis (Serrano et al. 2000, de Wilde et al. 2012). By contrast, insulinomas have been shown to have a low frequency (17\%) of CDKN2A/p16INK4a alterations (Bartsch et al. 2000).

\section{Methylation of other loci may be relevant to pNET development}

TIMP3 promoter hypermethylation has been demonstrated in $44 \%$ of pNETs and correlated with the presence of metastases. Interestingly, none of the five insulinomas in this cohort showed methylation at this site (Wild et al. 2003). The MGMT promoter is methylated in $40 \%$ of pNET and may be a useful predictive biomarker of response to temozolomide chemotherapy (Dammann et al. 2003b). Only 6\% of pNETs show hypermethylation of $V H L$ (compared with $18 \%$ showing deletion of the gene), suggesting that $V H L$ promoter methylation is not a significant mechanism of tumorigenesis (Schmitt et al. 2009).

\section{CPG island methylator phenotype positivity is a poor prognostic marker in PNET}

CpG island methylator phenotype (CIMP) positivity (a term denoting a high degree of methylation across multiple CpG sites) in $20 \%$ of a cohort of 71 mixed pancreatic and gastrointestinal NETs corresponded with higher grade tumours (Ki67>10\%), while CIMP negativity was associated with improved overall survival (Arnold et al. 2007). This is in keeping with methylation at three or more loci of selected candidate genes being associated with early recurrence and worse prognosis in a separate study (House et al. 2003).

\section{Insulinomas are distinguished from other pNET subtypes through differences in DNA methylation}

A large study with a mixed cohort of 62 NET cases were analysed for DNA methylation at three regions associated with the IGF2 gene previously identified as differentially methylated in mouse models (Fontaniere et al. 2006, Dejeux et al. 2009). The gastrinomas, non-functional pNETs and small intestinal NETs in the cohort exhibited hypomethylation of varying degrees at these sites; by contrast, the 11 insulinomas were hypermethylated at these regions. This correlated with insulinoma-specific overexpression of IGF2 RNA and protein thought to be caused by loss of imprinting and reactivation of the normally silent maternal allele (Dejeux et al. 2009).

Promoter methylation of MLH1 has been identified in $31 \%$ of insulinomas and correlated with poor prognosis (Mei et al. 2009), and unlike most pNETs, TIMP3 and CDKN2A/p16INK4a methylation are not common features of insulinomas (Bartsch et al. 2000, Wild et al. 2003). In Table 1, we summarise genes known to be methylated in pNET as well as other anatomical origins.

\section{Chromatin remodellers in PNET}

In a recent study (Jiao et al. 2011), exome sequencing was performed in ten sporadic pNETs followed by Sanger sequencing validation in a cohort of 58 pNETs identifying commonly mutated genes implicated in chromatin remodelling. Forty-four per cent of tumours had inactivating mutations of MEN1 and $43 \%$ had mutations in either DAXX or ATRX (25 and 18\% respectively) (death domain-associated protein or alpha thalassemia/mental retardation syndrome X-linked) (Jiao et al. 2011).

MEN1 encodes the transcription factor menin, which recruits the H3K4me3 histone methyltransferase mixed lineage leukaemia complex that plays an essential role in chromatin remodelling (Agarwal et al. 1999). ATRX and $D A X X$ had not previously been associated with NETs and are novel tumour suppressor genes, although ATRX has previously been implicated in glioma. The proteins encoded by $A T R X$ and $D A X X$ have multiple functions

Published by Bioscientifica Ltd. 
Table 1 Summary of loci identified with aberrant methylation in neuroendocrine tumours.

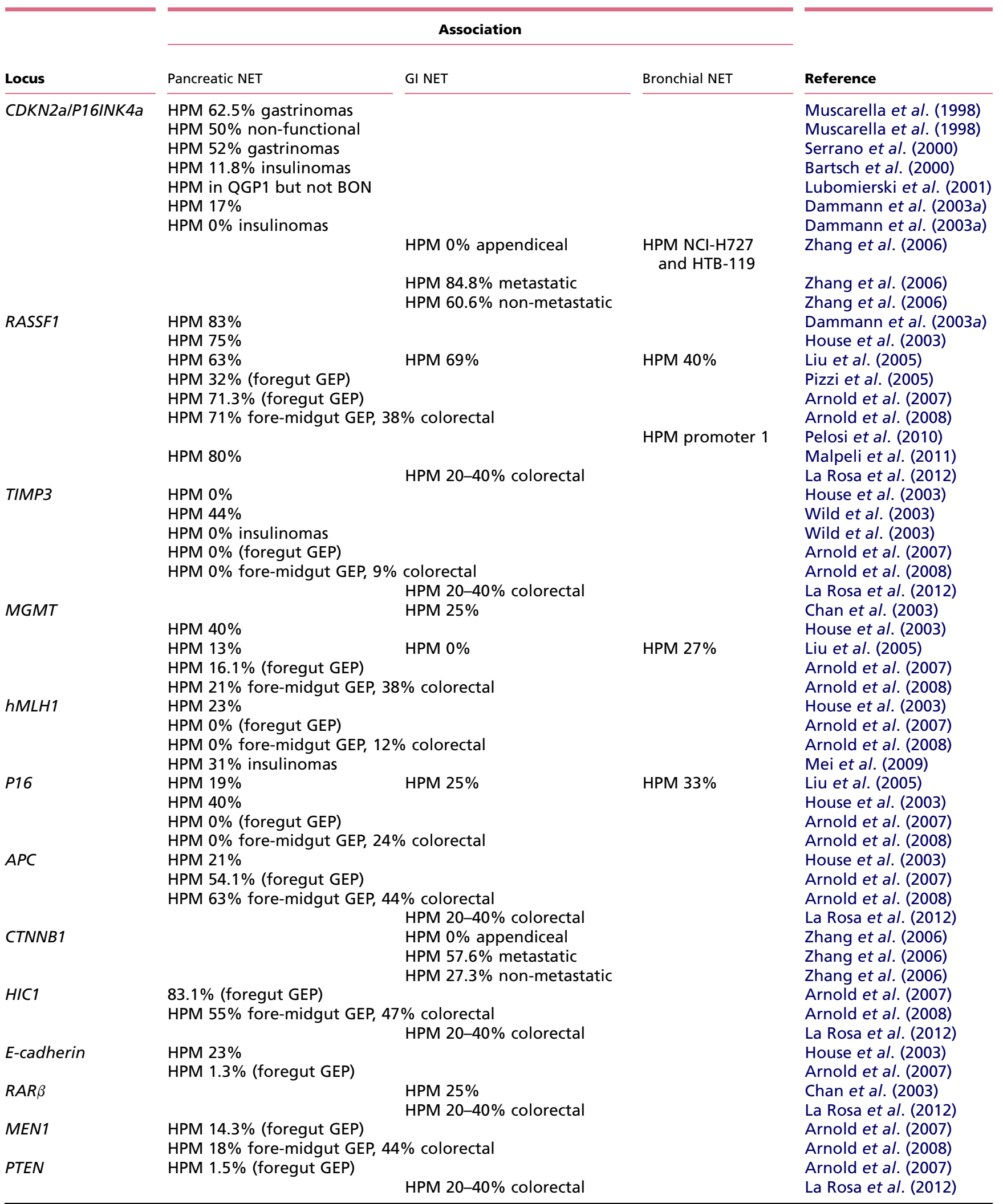

http://erc.endocrinology-journals.org DOI: 10.1530/ERC-12-0338
(C) 2013 Society for Endocrinology Printed in Great Britain
Published by Bioscientifica Ltd. 


\begin{tabular}{|c|c|c|c|c|}
\hline \multirow[b]{2}{*}{ Locus } & \multicolumn{3}{|c|}{ Association } & \multirow[b]{2}{*}{ Reference } \\
\hline & Pancreatic NET & GI NET & Bronchial NET & \\
\hline \multirow{2}{*}{ P14 } & HPM 0\% & & & House et al. (2003) \\
\hline & HPM $44 \%$ & HPM 69\% & HPM 33\% & Liu et al. (2005) \\
\hline GATA5 & & HPM $>80 \%$ colorectal & & La Rosa et al. (2012) \\
\hline ESR1 & & HPM $80 \%$ colorectal & & La Rosa et al. (2012) \\
\hline GST & HPM $0 \%$ & & & House et al. (2003) \\
\hline RUNX3 & HPM $6.6 \%$ (foregut GEP) & & & Arnold et al. (2007) \\
\hline P14 & & HPM $44 \%$ & & Chan et al. (2003) \\
\hline THBS1 & & HPM $44 \%$ & & Chan et al. (2003) \\
\hline$R A R(R A R A)$ & HPM $25 \%$ & & & House et al. (2003) \\
\hline P73 (TP73) & HPM $17 \%$ & & & House et al. (2003) \\
\hline$V H L$ & HPM $6 \%$ & & & Schmitt et al. (2009) \\
\hline WT1 & & HPM $60-80 \%$ colorectal & & La Rosa et al. (2012) \\
\hline $\mathrm{CDH} 13$ & & HPM $40-60 \%$ colorectal & & La Rosa et al. (2012) \\
\hline CIMP status & CIMP + ve $29 \%$ fore-midgu & P, $59 \%$ colorectal & & Arnold et al. (2008) \\
\hline
\end{tabular}

HPM, hypermethylated; NET, neuroendocrine tumour; GEP, gastroenteropancreatic; MSP, methylation-specific PCR; GI, gastrointestinal; DMR, differentially methylated region; DNMT, DNA methyltransferase; CIMP, CpG island methylator phenotype; MANEC, mixed adenoneuroendocrine carcinoma.

including chromatin remodelling during heterochromatin assembly at repetitive guanine-rich regions (such as telomeres) where they are required for incorporation of the histone variant H3.3 (Heaphy et al. 2011a). Mutations in $A T R X$ and $D A X X$ were mutually exclusive but overlapped with MEN1 mutations in 16 cases (23.5\%). The presence of mutations in $A T R X / D A X X$ was associated with improved prognosis.

NETs harbouring $A T R X / D A X X$ mutations have been shown to demonstrate alternative lengthening of telomeres (ALT), indicating that they do not increase activity of telomerase in the face of extensive cell proliferation but maintain telomeres through alternative mechanisms (Heaphy et al. 2011a). All 19 tumours with ATRX/DAXX mutations from the Jiao study were found to have ALT positivity - a 100\% correlation $(P<0.008$ for each gene), while in human cancers in general, the ALT phenotype is present in only 3\% (Heaphy et al. 2011b). The association of $A T R X / D A X X$ with ALT has subsequently been confirmed in other tumour types including glioblastoma and osteosarcoma substantiating the role of $A T R X / D A X X$ in telomere maintenance (Schwartzentruber et al. 2012). ALT phenotype has been found to be a favourable prognostic factor, possibly due to the reduction of chromosomal instability observed in these tumours (Ulaner et al. 2003).

The role of $A T R X / D A X X$ was subsequently investigated in 28 multiple endocrine neoplasia 1 (MEN1) syndrome-related pNETs, loss of $A T R X / D A X X$ expression occurred in only $6 \%$ of these tumours, all of which were $>3 \mathrm{~cm}$ in size and demonstrated ALT phenotype, suggesting that $A T R X / D A X X$ mutation is a late event in MEN1-associated pNET development (de Wilde et al. 2012). Forty-seven microadenomas $(<0.5 \mathrm{~cm})$ were included in the study, none of which showed $A T R X / D A X X$ mutation or ALT positivity.

There has been little research investigating histone modifications in pNETs; however, given the frequency and prognostic impact of modifications related to chromatin remodelling, it is recommended that histone modifications should be studied more extensively in pNETs. One study was identified assessing mutation or aberrant expression of HDAC11 (selected for study due to its position at locus 3 p25 which is associated with a high rate of loss of heterozygosity in pNETs) in a small cohort of sporadic malignant pNETs detected no tumour specific events suggesting that HDAC11 is unlikely to play a role in these tumours (Chung et al. 1997b, Barghorn et al. 2001).

\section{miRNA expression in pNET}

\section{miRNAs 103/107/155 can distinguish pNET from normal pancreatic tissue}

Roldo et al. (2006) investigated the global expression of miRNAs in pNETs. Analysis of global miRNA expression of 44 pancreatic primary tumours determined a common pattern of miRNA expression distinguishing pNETs from normal pancreas: expression of miR-103 and miR-107 associated with lack of expression of miR-155.

Published by Bioscientifica Ltd. 
Overexpression of miR-204 was specific to insulinomas and correlated with immunohistochemical expression of insulin. MiR-21 was strongly associated with a high Ki67 proliferation index and liver metastases and may be a useful prognostic marker.

\section{Gastrointestinal NETs}

Approximately two thirds of gastroenteropancreatic NET arise from the intestine, these comprise foregut, the classical 'midgut' NETs, and the typically higher grade hindgut and rectal NETs, which are associated with poorer prognosis. Interest in the methylation status of GI NET has been encouraged by understanding of the role of methylation and CIMP in colorectal adenocarcinoma. Methylation of certain loci in GI NET appears to be related to metastatic progression, and there may be a distinct subgroup of colorectal cancer patients with CIMP +/MSI + who experience an improved overall prognosis. The limited studies of histone modifications in these tumours have been less informative.

\section{DNA methylation in gastrointestinal NET}

\section{Gastrointestinal and pNETs have different methylation patterns}

One of the earliest studies of DNA methylation in NET compared with CpG island methylation in 16 GI NETs and 11 pNETs showed differing profiles of methylation across a panel of 14 candidate genes commonly implicated in gastrointestinal malignancy, reflecting differing molecular pathogenesis. Specifically, GI NETs were found to be significantly more frequently methylated at the promoter regions of the following genes compared to pNETs: $M G M T$ ( 25 vs $0 \% P=0.03$ ), THSB1 (44 vs $9 \% P=0.04$ ), $P 14$ ( 44 vs $9 \% P=0.04$ ), $P 16$ ( 31 vs $9 \%$ ) and $R A R \beta$ ( 25 vs $0 \% P=0.03$ ). PNETs were more frequently methylated at $E R(64 \%)$, and of note, MEN1 was not methylated in any of the samples (Chan et al. 2003).

\section{Global hypomethylation is a feature of gastrointestinal NET}

Methylation of repeat elements such as long interspersed nucleotide elements (LINE1 (L1RE1)) and Alu is a surrogate for global methylation levels. A study of 35 NETs (15 ileal, 11 pancreatic and nine others) demonstrated that all tumour samples were hypomethylated relative to normal tissue at these sites (LINE1 P=0.04, Alu P=0.001).
Global hypomethylation was more prevalent in GI NET than pancreatic and was correlated with poor prognosis, lymph node metastasis and loss of chromosome 18 (Choi et al. 2007).

However, in a more recent study of 43 GI NETs and 15 pNETs, LINE1 hypomethylation was identified in 100\% pNETs, $50 \%$ gastric NETs, $82 \%$ midgut NETs and $100 \%$ colorectal NETs while NETs metastatic to lymph nodes were less frequently hypomethylated than non-metastatic NET (Stricker et al. 2012). We can conclude that global hypomethylation is a feature of pNETs, and while it is generally considered a poor prognostic marker in most solid tumours, the prognostic implication in pNET remains to be determined.

\section{RASSF1A and CTNNB1 promoters are frequently methylated in gastrointestinal NETs}

Two interesting studies of RASSF1A methylation in GI NET have been performed. In the first study, RASSF $1 A$ methylation was identified in 32\% (20/62) GI NETs and was restricted to foregut tumours (Pizzi et al. 2005). The second study determined that frequency of RASSF $1 \mathrm{~A}$ methylation increased in metastatic lesions compared with primary tumours in a study of 33 midgut NET cases (61\% methylated in primary tumours vs $85 \%$ in matched metastatic lesions). CTNNB1 promoter methylation is also more frequent in metastatic than in primary GI NET tumours (57.6 vs $27.3 \% P=0.004$ ) and is not seen in normal tissue (Zhang et al. 2006). None of the six appendiceal NETs included in the study (all nonmetastatic as most appendiceal NETs) displayed RASSF1A or CTNNB1 methylation (Zhang et al. 2006). These results suggest that RASSF1A may be involved in the development of endocrine tumours of the foregut and midgut but not hindgut and that RASSF1A/CTNNB1 may be associated with progression to metastasis.

\section{CIMP may be a prognostic biomarker for colorectal NET}

Recent studies have demonstrated CIMP positivity in $37-59 \%$ of poorly differentiated colorectal NETs (Arnold et al. 2008, La Rosa et al. 2012) compared with $29 \%$ of well-differentiated fore/midgut NETs. In one study, survival was not influenced by CIMP status; however, La Rosa et al. demonstrated a 100\% correlation of CIMP positivity with the presence of microsatellite instability, and this was associated with better prognosis (MSI/CIMP + ve vs others $P=0.04$ ).

Published by Bioscientifica Ltd. 
Expression of DNMT1, -3A and -3B has been demonstrated to be significantly higher in stage IV GEP NET than in stage I or II. DNMT3A (a de novo methyltransferase) was significantly higher in poorly differentiated carcinomas relative to well-differentiated tumours $(P<0.01)$, and DNMT3A and $-3 \mathrm{~B}$ both showed significantly lower expression in midgut NET relative to fore- or hindgut tumours. We can conclude that overexpression of DNMT1, $-3 \mathrm{~A}$ and $-3 \mathrm{~B}$ is a common feature of GEP NET, and these enzymes may play a role in the development of NET and are therefore a potential novel therapeutic target (Rahman et al. 2010). The relationship between DNMT activity and CIMP is not fully characterised and further large studies are required to resolve the relationship between the activity of these enzymes, methylation status and prognosis in GI NET.

\section{Methylation of other loci may be relevant in colorectal NET}

In a study including 34 colorectal and 38 fore-midgut NETs, promoter methylation of $C D K N 2 A / p 16 I N K 4 a$, $h M L H 1$ and TIMP3 was only detected in NET of colorectal origin. CDKN2A/p16INK4a methylation was only present in poorly differentiated colorectal NET $(P=0.01)$ and was a more significant prognostic marker of poor outcome than Ki67 ( $P=0.0004)$ (Arnold et al. 2008). Altered expression of MLH1 by both genetic and epigenetic mechanisms is an area of exciting research in colorectal adenocarcinoma and may be significant in the development of both endocrine and exocrine tumours of this site. Methylation of the GATA4/5 promoter (a gene known to be frequently methylated in colorectal adenocarcinoma) is present in $>90 \%$ of colorectal NET and MANEC (La Rosa et al. 2012). Table 1 provides a summary of loci differentially methylated in GI NET.

\section{Histone modifications in gastrointestinal NET}

Research of histone modifications in NETs is limited to studies on small numbers of tumours. H3K4diMe and the associated methylating (Ash2 complex) and demethylating (LSD1) enzymes were studied in gastrointestinal carcinomas including a group of 16 mostly low-grade primary intestinal NETs (Magerl et al. 2010). Up to 100\% of neuroendocrine carcinomas exhibited strong immunostaining for Ash2 and LSD1, while H3K4diMe was strongly expressed in 93\% of neuroendocrine carcinomas, other carcinomas (such as HCC and pancreatic adenocarcinomas) showing lower expression. In matched normal tissue, all three markers showed weak expression. This suggests a potential role for modifications at the histone H3K4 locus in intestinal NETs but requires further validation.

Histone $\mathrm{H} 1 \mathrm{x}$ has been demonstrated to be highly expressed in NETs but also in the corresponding nonneoplastic neuroendocrine cells of the pancreas and small intestine and therefore may reflect cell of origin rather than tumorigenic feature (Warneboldt et al. 2008).

\section{miRNA expression in gastrointestinal NET}

\section{MiR-133a is down-regulated in metastatic progression of ileal NET}

Two miRNA expression profile analyses provide evidence that miRNAs are dysregulated specifically in ileal NET progression: down-regulation of miR-133a, $-145,-146,-222$ and $-10 b$ and up-regulation of miR-183, -488 and $-19 a+b$ in metastatic tumours compared to primary tumours (Ruebel et al. 2010) and up-regulation of miR-96, -182, -183, -196a and -200a and down-regulation of miR-31, -129-5p, -133a and -215 (Li et al. 2012). These results suggest that miRNAs may play a role in GI NET progression, in particular miR-133a that was identified in both studies and may be a useful focus for further investigation.

\section{miRNAs can distinguish colorectal NET from adenocarcinoma}

A case of colorectal NET was included in comparison of miRNA expression in colorectal adenocarcinoma and normal mucosa, which identified 38 up-regulated miRNAs in colorectal NET compared with the normal mucosa. Of these, only six were found to be up-regulated in colorectal adenocarcinoma, suggesting distinct miRNA expression pattern in colorectal NET compared with adenocarcinomas (Hamfjord et al. 2012). Four miRNAs identified as up-regulated in colorectal NET were also noted in the analyses of ileal NET described earlier: miR96, -182, -196a and -488; these would be good candidates for further investigation; however, it must be noted that this study only analysed one NET case and analysis of a larger sample size and validation of the data is required.

\section{Bronchial NETs}

Bronchial NETs can be classified by cellular morphology into small-cell (SCLC), large-cell (LCNEC), 'atypical' carcinoid (AC) and 'typical' carcinoid (TC) tumours. In this review, we focus on the typical and atypical carcinoid subtypes of bronchial NET.

Published by Bioscientifica Ltd. 


\section{DNA methylation in bronchial NET}

\section{The RASSF1 promoter is hypermethylated in} bronchial NET

Analysis of methylation of the RASSF1 promoter regions in a cohort of 58 bronchial NETs, matched normal tissue and 20 control non-small-cell lung cancers (NSCLC) identified that promoter 1 was hypermethylated in NET but not normal tissue or non-endocrine tumours. The degree of hypermethylation correlated with tumour grade and corresponding global loss of RASSF1A/E mRNA expression (Pelosi et al. 2010), and RASSF 1 promoter 1 methylation may represent a useful biomarker in lung NET to differentiate high- from low-grade NET. Up-regulation of RASSF1C was found to be an independent adverse prognostic factor in high-grade bronchial NETs (Pelosi et al. 2010).

\section{P15.5 promoter methylation may be implicated in low-grade bronchial NET}

Similar to the tumour suppressor gene CDKN2A/P16INK $4 a$, P15INK4b (CDKN2B) also encodes a cyclin-dependent kinase inhibitor, which functions in cell cycle regulation, but its role in tumorigenesis is less well characterised. A series of five low-grade and 15 high-grade bronchial NETs showed aberrant methylation at the $5^{\prime}$-region of the $p 15 I N K 4 b$ gene in $15 \%$ of tumours but not in control/ normal lung tissue, and there was a highly variable expression of isoform $p 15.5$ in the low-grade bronchial NETs, suggesting potential involvement of this gene in the 'carcinoid'-type bronchial tumours. P15 status was shown to be independent of $P 16$ and P14 (Chaussade et al. 2001).

\section{Histone modifications in bronchial NET}

Histone 4 modifications can differentiate low- and high-grade bronchial NETs

A case series of 32 bronchial NETs demonstrated progressive loss of two different histone marks, H4KA16 and H4KM20, from low- to high-grade tumours, and found that Ki67 was inversely correlated with both H4KA16 and H4KM20 $(P<0.05)$ (Li et al. 2011).

\section{$E Z H 2$ is strongly expressed in high-grade bronchial NET}

Increased expression of enhancer of zeste homolog 2 $(E Z H 2)$, a molecule involved in methylation of histone H3 (H3K27), has been demonstrated in many human malignancies and is associated with poor prognosis
(Bachmann et al. 2006). EZH2 was demonstrated to be strongly expressed in all SCLC and LCNEC (80-90\% of cells) in a cohort of 54 bronchial NETs, but only rare scattered expression was seen in typical and atypical bronchial NETs (Findeis-Hosey et al. 2011). EZH2 may play a role in the development of high-grade NETs and may be a useful diagnostic biomarker.

\section{miRNA expression in bronchial NET}

\section{miRNA-21 and -155 distinguish high- and low-grade bronchial NETs}

In a recent study evaluating expression of selected miRNAs in 63 bronchial NETs, miRNA-21 and -155 were found to be up-regulated in high-grade tumours but not in TC/AC, and miRNA-21 was found to be significantly up-regulated in metastatic low-grade NETs compared with nonmetastatic tumours (Lee et al. 2012). These results require validation but suggest that miRNA profiles may be utilised as diagnostic and prognostic biomarkers.

Table 2 summarises the current state of knowledge of the role of miRNA in NET. Interestingly, miRNA-155 has been identified as a biomarker of both pancreatic (down-regulated) and bronchial NETs (up-regulated), tumours of foregut embryological origin. A definitive role for miRNA involvement in NET development and signalling pathways still needs to be determined and further validation studies were performed with larger sample sets.

\section{Rarer NETs}

There is limited research into the impact of epigenetic changes on rare NET subtypes, and there are no published reports of any epigenetic research performed on thymic NETs.

\section{Hypermethylation of RASSF1A and p14ARF promoter regions is frequent in Merkel cell carcinomas}

The pathogenesis of Merkel cell carcinomas (MCCs) is poorly understood. Two studies have been performed investigating epigenetics in MCC, both candidate-driven analyses of promoter methylation, which demonstrated promoter hypermethylation of RASSF1A (51\%), p14ARF (42\%) and CDKN2A/p16INK4a (5-22\%) (Lassacher et al. 2008, Helmbold et al. 2009). The Merkel cell polyomavirus has recently been demonstrated to encode and express an miRNA MCV-miR-M1-5p in 50\% of MCCs, which may play a pathogenic role in tumour development (Lee et al. 2011). No correlation was demonstrated

Published by Bioscientifica Ltd. 
Table 2 Summary of miRNA associated with neuroendocrine tumours.

\begin{tabular}{|c|c|}
\hline miRNA & Pancreatic NET \\
\hline miR-204: up-regulated & $\begin{array}{l}\text { Associated with } \\
\text { insulinoma }\end{array}$ \\
\hline miR-103, -107: up-regulated & $\begin{array}{l}\text { Distinguishes pNET } \\
\text { from normal }\end{array}$ \\
\hline $\begin{array}{l}\text { miR-155: down-regulated } \\
\text { miR-10b, -133a, }-145,-146,-122 \text { : } \\
\text { down-regulated }\end{array}$ & \\
\hline $\begin{array}{l}\text { miR-183, }-488,-19 a+b: \text { up-regulated } \\
\text { miR-31, }-129-5 p,-133 a,-125: \\
\text { down-regulated }\end{array}$ & \\
\hline $\begin{array}{l}\text { miR-96, -182, -183, -196a, 200a: } \\
\text { up-regulated }\end{array}$ & \\
\hline $\begin{array}{l}\text { miR-653, }-7,-489,1224-5 p: \\
\text { up-regulated }\end{array}$ & \\
\hline miR-21, -155: up-regulated & \\
\hline
\end{tabular}

Association

\author{
Associated with \\ metastatic ileal NET \\ Associated with \\ metastatic small \\ intestinal NET \\ Associated with \\ colorectal NET \\ (vs normal mucosa)
}

Bronchial NET

Reference

Roldo et al. (2006)

Roldo et al. (2006)

Ruebel et al. (2010)

Li et al. (2012)

Hamfjord et al. (2012)

Associated with Lee et al. (2012) high-grade NET

NET, neuroendocrine tumour; miRNA, microRNA.

between polyomavirus infection and methylation status (Helmbold et al. 2009).

\section{Promoter hypermethylation of CDKN2A/p16INK4a is prognostic in paragangliomas}

Promoter hypermethylation of $C D K N 2 A / p 16 I N K 4 a$ is present in $100 \%$ of paragangliomas with succinate dehydrogenase complex subunit B $(S D H B)$ mutation and is associated with metastasis and poorer prognosis. MEN2/RET-associated paragangliomas in contrast did not exhibit significant hypermethylation (Kiss et al. 2008, 2013). CIMP positivity is present in 9\% of paragangliomas and is associated with malignant behaviour (Geli et al. 2008).

\section{Global hypomethylation and IGF2 promoter hypermethylation are associated with malignant behaviour of adrenocortical tumours}

Malignant adrenocortical tumours (ACTs) are globally hypomethylated relative to benign tumours (which shared most of their methylation patterns with normal tissue). Two groups have analysed hypermethylation in ACT identifying 212 hypermethylated CpG islands and 52 hypermethylated promoter loci respectively. Genome wide profiling of ACT can distinguish methylation patterns of normal and malignant tumours, specifically hypermethylation of CDKN2A and GATA4 is present in

http://erc.endocrinology-journals.org DOI: $10.1530 /$ ERC-12-0338
(C) 2013 Society for Endocrinology Printed in Great Britain
ACT but not in normal tissue, while IGF2 promoter hypermethylation is identified in malignant ACT but not in normal tissue or benign tumours (Fonseca et al. 2012, Rechache et al. 2012). CIMP positivity in ACT has been associated with poor survival (Barreau et al. 2013). Treatment of an ACT cell line (NCI-H295R) with decitabine restored expression of hypermethylated genes and has anti-proliferative effects (Suh et al. 2010, Fonseca et al. 2012).

\section{miRNA profiling distinguishes malignant and benign ACTs}

Several investigations of the role of miRNA in ACTs have been performed in recent years and have demonstrated association of malignant ACT with the following expression patterns: down-regulation of miR-100, $-125 \mathrm{~b}$ and -195 and up-regulation of miR-483-5p (Patterson et al. 2011); up-regulation of miR-335 and -675 (Schmitz et al. 2011); up-regulation of miR-195 and -483-5p (Soon et al. 2009); up-regulation of miR-184 and -503 and down-regulation of miR-511 and -214 (Tombol et al. 2009); up-regulation of miR-503, -1202 and -1275 (Ozata et al. 2011). Inhibition of miR-483-3p or $-483-5 p$ and overexpression of miR-195 or -497 reduced cell proliferation in human NCI-H295R ACT cells (Ozata et al. 2011). A comprehensive review of dysregulation of miRNA in ACTs has recently been published (Singh et al. 2012).

Published by Bioscientifica Ltd. 
11p15.5 imprinted genes may be pathogenic in phaeochromocytoma

Loss of imprinting of the 11p15.5 allele (which contains IGF2) has been identified in epigenetic analysis of phaeochromocytomas (both sporadic and VHL associated) (Astuti et al. 2005, Margetts et al. 2005). Other promoter regions found to be aberrantly methylated in phaeochromocytoma include HIC1 (82\%) and CASP8 (31\%) (Margetts et al. 2005); HSP47 (SERPINH1) (52\%), HOXA9 (17\%) and OPCML (12\%)(Margetts et al. 2008). Methylation patterns were found to be similar in neuroblastoma tumours (Margetts et al. 2005). Promoter regions of VHL, $S D H B$ and $S D H D$ are demonstrably unmethylated in sporadic phaeochromocytomas (Cascon et al. 2004).

\section{miRNA profiling can identify malignant and recurring phaeochromocytomas}

Three comparative analyses of benign and malignant phaeochromocytoma miRNA profiles have been performed in recent years. Overexpression of miR-483-5p, -183 and -101 (Patterson et al. 2012); overexpression of miR-483-5p and underexpression of miR-15a and -16 (Meyer-Rochow et al. 2010); and overexpression of miR-1225-3p (Tombol et al. 2010) have been identified as markers of malignant or recurring tumours. MiR-483-5p has been identified in investigation of both phaeochromocytomas and ACTs and is an interesting candidate for further investigation given its location at 11p15.5 within the second intron of IGF2 and implication in other solid malignant tumours (Meyer-Rochow et al. 2010).

\section{Therapeutic approaches using epigenetic targets}

The use of novel targeted epigenetic therapies is an attractive concept due to the prevalence of modifications found in malignant tumours, and the inherent reversibility of DNA methylation and chromatin modifications. Despite this, epigenetic therapies have so far shown limited efficacy in solid tumours; however, preclinical and early clinical trials in NET are promising.

\section{DNMT inhibitors suppress NET cell growth}

The DNMT inhibitor azacytidine has been shown to cause a dose-dependent reduction in tumour cell proliferation in three NET cell lines (midgut: CDNT2.5, bronchial: NCI-H727 and pancreatic lymph node metastasis: BON1). Growth inhibition was associated by significant reduction in chromogranin A and neuron-specific enolase (Alexander et al. 2010). Two bronchial NET cell lines (NCI-H727 bronchial 'carcinoid' and HTB-119 SCLC) showed re-expression of RASSF1A mRNA after treatment with decitabine (Zhang et al. 2006), while treatment of QGP1 pNET cell lines with decitabine restored CDKN2A/p16INK4a and caused significant growth inhibition (Habbe et al.2007). The anti-proliferative effect is likely to be due to restoration of multiple genes silenced by pathogenic de novo methylation. Differential expression of 48 genes has been identified in QGP1 cells after treatment with decitabine, including 23 in which expression decreased after treatment. Many of these genes are known to be involved in cellular proliferation, apoptosis and development of metastasis and may play a role in pNET development (Habbe et al. 2007).

\section{HDACis suppress NET cell growth}

Functional analysis of three different HDAC inhibitors trichostatin A, sodium butyrate and entinostat - has been carried out on neuroendocrine cell lines (insulinoma: CM and pancreatic lymph node metastasis: BON1) showing dose-dependent inhibition of proliferation, cell cycle arrest and induction of apoptosis. The addition of somatostatin or octreotide did not affect the outcome (Baradari et al. 2006).

Valproic acid (VPA) (a class I and IIa HDAC inhibitor) in combination with lithium chloride has been shown to suppress chromogranin A levels while reducing cellular growth in pancreatic (BON) and pulmonary (NCI-H727) NET cell lines (Adler et al. 2009), while VPA alone up-regulates notch1 and suppresses growth in gastrointestinal and bronchial NET cell lines (Greenblatt et al. 2007). Notch1 is a transmembrane receptor that translocates to the nucleus upon ligand binding and regulates gene transcription, acting as a tumour suppressor in some human cancers (Radtke \& Raj 2003). Activation of Notch 1 has been shown to suppress growth in NET cell lines and is associated with reduction of NET tumour markers (Kunnimalaiyaan et al. 2006).

\section{Early phase clinical trials of HDACis in NET are inconclusive}

A pilot phase II trial of VPA in low-grade NET was conducted in eight patients (two pNETs and six midgut NETs) receiving $500 \mathrm{mg}$ oral VPA twice per day with dose adjustment to maintain therapeutic serum levels. Notch1 signalling was absent in all tumours before treatment and was up-regulated with VPA. One patient had an unconfirmed partial response and four had stable disease, tumour markers improved in five out of seven (Mohammed et al. 2011). This well-tolerated agent may have a role in the

Published by Bioscientifica Ltd. 
management of low-grade NETs and is currently being trialled in many different tumour types.

Two trials of HDAC inhibitors have been terminated early: in 2006, depsipeptide was associated with an unexpectedly high rate of cardiac adverse events and a phase II trial in NET patients was terminated (Shah et al. 2006); and in 2012, a phase II trial panobinostat in a mixed cohort of 15 GEP NET patients was terminated due to lack of apparent benefit. In this single-arm trial, all patients received panobinostat $20 \mathrm{mg}$ once daily three times per week. The stable disease rate was $92.3 \%$ and median progression-free survival was 11.8 months; however, response rate was $0 \%$ and stabilisation rate needs to be considered in context of the typical slow growth of low-grade NET. Thrombocytopaenia and fatigue were the most frequent toxicities (Rajguru et al. 2012).

While in vitro results of epigenetic therapies on NET cell lines appear promising, clinical trials have so far not demonstrated significant benefit to patients but are limited by the rarity of NET and challenges of performing early phase trials in this patient group. Demethylating agents have not yet been trialled in the NET population and the field of miRNA therapeutics is still in its infancy. Predictive biomarkers are required to assist patient stratification for this novel class of therapeutics, and as specificity of the agents to target a particular epigenetic change improves so, toxicity is likely to reduce and patient benefit increase.

\section{Summary}

Epigenetic changes are likely to play a key role in NET development and progress is being made in identifying potential diagnostic and prognostic epigenetic biomarkers for these tumours. The apparent disparity in epigenetic states of NETs of different cellular origins is intriguing and is likely to reflect diverse tumorigenic processes. Increased promoter methylation of CDKN2A/ P16INK4a is a typical feature of gastrinomas, while methylation of IGF2 and MLH1 appears to be characteristic of insulinoma. This has implications for targeted therapeutics and personalisation of patient management and needs to be further explored in large-scale studies. Methylation of RASSF1A is a frequent finding in NETs of all origins and has prognostic impact, suggesting a potential 'driver' role in development of these tumours and a potentially effective drug target. CIMP positivity is associated with worse prognosis in pNETs but improved prognosis in colorectal NET. EZH2 expression distinguishes between high- and low-grade bronchial NETs, as do histone modifications H4KA16 and K4KM20.
Characteristic miRNA signatures of NET of all subtypes are being identified that distinguish tumour from normal tissue, as well as some with prognostic significance.

A key development in our understanding of pNET has been the identification of $A T R X / D A X X$ mutations in $43 \%$ of tumours and the associated ALT phenotype (Jiao et al. 2011). These are associated with improved prognosis in pNET and are suitable for clinical application as a prognostic biomarker. The identification of these mutations and the subsequent chromatin remodelling illustrate the synergistic nature of genetic and epigenetic regulation.

The field of epigenetic-targeted agents is still in development, and despite promising in vitro results in many solid tumours the only real clinical applications with FDA approval so far have come in haematological malignancies. However, there is enormous interest and investment, and with many novel agents entering clinical trials, and increasing personalisation/targeting of therapy, we anticipate that positive results in solid tumours will soon follow.

We have presented a comprehensive overview of current understanding of epigenetic changes in NETs. In many cases, the data presented is identified through small candidate-driven studies of mixed cohorts of NET cases; in consequence, some outcomes appear conflicting and drawing decisive conclusions is difficult. There are multiple mechanisms regulating gene transcription and cellular proliferation in NET and identifying the most powerful tumorigenic drivers within the group is challenging. Commonly mutated oncogenes in other solid tumours play little or no pathogenic role in NET and therefore epigenetic changes are good candidates for pathogenic drivers. The findings presented in this review give insight into the pathobiology of NET and provide rationale for the application of novel therapeutics and further avenues of research. There is clear requirement for further collaborative large-scale genome wide integrated (epi)genetic studies, the results of which will clarify what is currently a complex field of research.

\section{Declaration of interest}

The authors declare that there is no conflict of interest that could be perceived as prejudicing the impartiality of the review.

\section{Funding}

This research did not receive any specific grant from any funding agency in the public, commercial or not-for-profit sector. All authors are in receipt of research grants from Cancer Research UK and The Raymond and Beverly Sackler Foundation.

Published by Bioscientifica Ltd. 


\section{Author contribution statement}

All authors made significant contributions to writing the manuscript.

\section{References}

Adler JT, Hottinger DG, Kunnimalaiyaan M \& Chen H 2009 Combination therapy with histone deacetylase inhibitors and lithium chloride: a novel treatment for carcinoid tumors. Annals of Surgical Oncology 16 481-486. (doi:10.1245/s10434-008-0194-6)

Agarwal SK, Guru SC, Heppner C, Erdos MR, Collins RM, Park SY, Saggar S, Chandrasekharappa SC, Collins FS, Spiegel AM et al. 1999 Menin interacts with the AP1 transcription factor JunD and represses JunD-activated transcription. Cell 96 143-152. (doi:10.1016/S00928674(00)80967-8)

Alexander VM, Roy M, Steffens KA, Kunnimalaiyaan M \& Chen H 2010 Azacytidine induces cell cycle arrest and suppression of neuroendocrine markers in carcinoids. International Journal of Clinical and Experimental Medicine 3 95-102.

Allfrey VG, Faulkner R \& Mirsky AE 1964 Acetylation and methylation of histones and their possible role in the regulation of RNA synthesis. PNAS 51 786-794. (doi:10.1073/pnas.51.5.786)

Arnold CN, Sosnowski A, Schmitt-Graff A, Arnold R \& Blum HE 2007 Analysis of molecular pathways in sporadic neuroendocrine tumors of the gastro-entero-pancreatic system. International Journal of Cancer 120 2157-2164. (doi:10.1002/ijc.22569)

Arnold CN, Nagasaka T, Goel A, Scharf I, Grabowski P, Sosnowski A, Schmitt-Graff A, Boland CR, Arnold R \& Blum HE 2008 Molecular characteristics and predictors of survival in patients with malignant neuroendocrine tumors. International Journal of Cancer 123 1556-1564. (doi:10.1002/ijc.23690)

Astuti D, Latif F, Wagner K, Gentle D, Cooper WN, Catchpoole D, Grundy R, Ferguson-Smith AC \& Maher ER 2005 Epigenetic alteration at the DLK1-GTL2 imprinted domain in human neoplasia: analysis of neuroblastoma, phaeochromocytoma and Wilms' tumour. British Journal of Cancer 92 1574-1580. (doi:10.1038/sj.bjc.6602478)

Bachmann IM, Halvorsen OJ, Collett K, Stefansson IM, Straume O, Haukaas SA, Salvesen HB, Otte AP \& Akslen LA 2006 EZH2 expression is associated with high proliferation rate and aggressive tumor subgroups in cutaneous melanoma and cancers of the endometrium, prostate, and breast. Journal of Clinical Oncology 24 268-273. (doi:10.1200/JCO.2005. 01.5180)

Baradari V, Huether A, Hopfner M, Schuppan D \& Scherubl H 2006 Antiproliferative and proapoptotic effects of histone deacetylase inhibitors on gastrointestinal neuroendocrine tumor cells. EndocrineRelated Cancer 13 1237-1250. (doi:10.1677/erc.1.01249)

Barghorn A, Komminoth P, Bachmann D, Rutimann K, Saremaslani P, Muletta-Feurer S, Perren A, Roth J, Heitz PU \& Speel EJ 2001 Deletion at 3 p25.3-p23 is frequently encountered in endocrine pancreatic tumours and is associated with metastatic progression. Journal of Pathology 194 451-458. (doi:10.1002/path.886)

Barlesi F, Giaccone G, Gallegos-Ruiz MI, Loundou A, Span SW, Lefesvre P, Kruyt FA \& Rodriguez JA 2007 Global histone modifications predict prognosis of resected non small-cell lung cancer. Journal of Clinical Oncology 25 4358-4364. (doi:10.1200/JCO.2007.11.2599)

Barreau O, Assie G, Wilmot-Roussel H, Ragazzon B, Baudry C, Perlemoine K, Rene-Corail F, Bertagna X, Dousset B, Hamzaoui N et al. 2013 Identification of a CpG island methylator phenotype in adrenocortical carcinomas. Journal of Clinical Endocrinology and Metabolism 98 E174-E184. (doi:10.1210/jc.2012-2993)

Bartsch DK, Kersting M, Wild A, Ramaswamy A, Gerdes B, Schuermann M, Simon B \& Rothmund M 2000 Low frequency of p16(INK4a) alterations in insulinomas. Digestion 62 171-177. (doi:10.1159/000007810)

Bauer W, Briner U, Doepfner W, Haller R, Huguenin R, Marbach P, Petcher TJ \& Pless 1982 SMS 201-995: a very potent and selective octapeptide analogue of somatostatin with prolonged action. Life Sciences 31 1133-1140. (doi:10.1016/0024-3205(82)90087-X)

Bernstein BE, Stamatoyannopoulos JA, Costello JF, Ren B, Milosavljevic A, Meissner A, Kellis M, Marra MA, Beaudet AL, Ecker JR et al. 2010 The NIH roadmap epigenomics mapping consortium. Nature Biotechnology 28 1045-1048. (doi:10.1038/nbt1010-1045)

Bestor TH 1992 Activation of mammalian DNA methyltransferase by cleavage of a Zn binding regulatory domain. EMBO Journal $\mathbf{1 1}$ 2611-2617.

Bruns C, Lewis I, Briner U, Meno-Tetang G \& Weckbecker G 2002 SOM230: a novel somatostatin peptidomimetic with broad somatotropin release inhibiting factor (SRIF) receptor binding and a unique antisecretory profile. European Journal of Endocrinology/European Federation of Endocrine Societies 146 707-716. (doi:10.1530/eje.0.1460707)

Cairns P, Esteller M, Herman JG, Schoenberg M, Jeronimo C, SanchezCespedes M, Chow NH, Grasso M, Wu L, Westra WB et al. 2001 Molecular detection of prostate cancer in urine by GSTP1 hypermethylation. Clinical Cancer Research 7 2727-2730.

Calin GA, Sevignani C, Dumitru CD, Hyslop T, Noch E, Yendamuri S, Shimizu M, Rattan S, Bullrich F, Negrini M et al. 2004 Human microRNA genes are frequently located at fragile sites and genomic regions involved in cancers. PNAS 101 2999-3004. (doi:10.1073/pnas. 0307323101)

Cascon A, Ruiz-Llorente S, Fraga MF, Leton R, Telleria D, Sastre J, Diez JJ, Martinez Diaz-Guerra G, Diaz Perez JA, Benitez J et al. 2004 Genetic and epigenetic profile of sporadic pheochromocytomas. Journal of Medical Genetics 41 e30. (doi:10.1136/jmg.2003.012658)

Catteau A, Harris WH, Xu CF \& Solomon E 1999 Methylation of the BRCA1 promoter region in sporadic breast and ovarian cancer: correlation with disease characteristics. Oncogene 18 1957-1965. (doi:10.1038/sj.onc. 1202509)

Chadwick LH 2012 The NIH Roadmap Epigenomics Program data resource. Epigenomics 4 317-324. (doi:10.2217/epi.12.18)

Chan AO, Kim SG, Bedeir A, Issa JP, Hamilton SR \& Rashid A 2003 CpG island methylation in carcinoid and pancreatic endocrine tumors. Oncogene 22 924-934. (doi:10.1038/sj.onc.1206123)

Chaussade L, Eymin B, Brambilla E \& Gazzeri S 2001 Expression of p15 and p15.5 products in neuroendocrine lung tumours: relationship with p15(INK4b) methylation status. Oncogene 20 6587-6596. (doi:10.1038/ sj.onc.1204798)

Chi AS \& Bernstein BE 2009 Developmental biology. Pluripotent chromatin state. Science 323 220-221. (doi:10.1126/science.1166261)

Choi IS, Estecio MR, Nagano Y, Kim do H, White JA, Yao JC, Issa JP \& Rashid A 2007 Hypomethylation of LINE-1 and Alu in well-differentiated neuroendocrine tumors (pancreatic endocrine tumors and carcinoid tumors). Modern Pathology 20 802-810. (doi:10.1038/modpathol.3800825)

Chung DC, Smith AP, Louis DN, Graeme-Cook F, Warshaw AL \& Arnold A $1997 a$ Analysis of the retinoblastoma tumour suppressor gene in pancreatic endocrine tumours. Clinical Endocrinology 47 523-528. (doi:10.1046/j.1365-2265.1997.2861110.x)

Chung DC, Smith AP, Louis DN, Graeme-Cook F, Warshaw AL \& Arnold A $1997 b$ A novel pancreatic endocrine tumor suppressor gene locus on chromosome $3 \mathrm{p}$ with clinical prognostic implications. Journal of Clinical Investigation 100 404-410. (doi:10.1172/JCI119547)

Clark SJ, Harrison J, Paul CL \& Frommer M 1994 High sensitivity mapping of methylated cytosines. Nucleic Acids Research 22 2990-2997. (doi:10.1093/nar/22.15.2990)

Dammann R, Li C, Yoon JH, Chin PL, Bates S \& Pfeifer GP 2000 Epigenetic inactivation of a RAS association domain family protein from the lung tumour suppressor locus 3p21.3. Nature Genetics 25 315-319. (doi:10.1038/77083)

Dammann R, Schagdarsurengin U, Liu L, Otto N, Gimm O, Dralle H, Boehm BO, Pfeifer GP \& Hoang-Vu C 2003a Frequent RASSF1A promoter hypermethylation and K-ras mutations in pancreatic carcinoma. Oncogene 22 3806-3812. (doi:10.1038/sj.onc.1206582) http://erc.endocrinology-journals.org DOI: 10.1530/ERC-12-0338
(C) 2013 Society for Endocrinology Printed in Great Britain 
Dammann R, Schagdarsurengin U, Strunnikova M, Rastetter M, Seidel C, Liu L, Tommasi S \& Pfeifer GP 2003b Epigenetic inactivation of the Rasassociation domain family 1 (RASSF1A) gene and its function in human carcinogenesis. Histology and Histopathology 18 665-677.

Dejeux E, Olaso R, Dousset B, Audebourg A, Gut IG, Terris B \& Tost J 2009 Hypermethylation of the IGF2 differentially methylated region 2 is a specific event in insulinomas leading to loss-of-imprinting and overexpression. Endocrine-Related Cancer 16 939-952. (doi:10.1677/ ERC-08-0331)

Eckhardt F, Beck S, Gut IG \& Berlin K 2004 Future potential of the Human Epigenome Project. Expert Review of Molecular Diagnostics 4 609-618. (doi:10.1586/14737159.4.5.609)

Eden A, Gaudet F, Waghmare A \& Jaenisch R 2003 Chromosomal instability and tumors promoted by DNA hypomethylation. Science 300 455. (doi:10.1126/science.1083557)

Estrabaud E, Lassot I, Blot G, Le Rouzic E, Tanchou V, Quemeneur E, Daviet L, Margottin-Goguet F \& Benarous R 2007 RASSF1C, an isoform of the tumor suppressor RASSF1A, promotes the accumulation of $\beta$-catenin by interacting with $\beta$ TrCP. Cancer Research 67 1054-1061. (doi:10.1158/0008-5472.CAN-06-2530)

Feil R \& Fraga MF 2011 Epigenetics and the environment: emerging patterns and implications. Nature Reviews. Genetics 13 97-109.

Feinberg AP \& Vogelstein B 1983 Hypomethylation distinguishes genes of some human cancers from their normal counterparts. Nature $\mathbf{3 0 1}$ 89-92. (doi:10.1038/301089a0)

Findeis-Hosey JJ, Huang J, Li F, Yang Q, McMahon LA \& Xu H 2011 Highgrade neuroendocrine carcinomas of the lung highly express enhancer of zeste homolog 2, but carcinoids do not. Human Pathology $\mathbf{4 2}$ 867-872. (doi:10.1016/j.humpath.2010.09.019)

Fonseca AL, Kugelberg J, Starker LF, Scholl U, Choi M, Hellman P, Akerstrom G, Westin G, Lifton RP, Bjorklund P et al. 2012 Comprehensive DNA methylation analysis of benign and malignant adrenocortical tumors. Genes, Chromosomes \& Cancer 51 949-960. (doi:10.1002/gcc.21978)

Fontaniere S, Tost J, Wierinckx A, Lachuer J, Lu J, Hussein N, Busato F, Gut I, Wang ZQ \& Zhang CX 2006 Gene expression profiling in insulinomas of Men1 $\beta$-cell mutant mice reveals early genetic and epigenetic events involved in pancreatic $\beta$-cell tumorigenesis. Endocrine-Related Cancer 13 1223-1236. (doi:10.1677/erc.1.01294)

Fraga MF, Herranz M, Espada J, Ballestar E, Paz MF, Ropero S, Erkek E, Bozdogan O, Peinado H, Niveleau A et al. 2004 A mouse skin multistage carcinogenesis model reflects the aberrant DNA methylation patterns of human tumors. Cancer Research 64 5527-5534. (doi:10.1158/00085472.CAN-03-4061)

Fraga MF, Ballestar E, Villar-Garea A, Boix-Chornet M, Espada J, Schotta G, Bonaldi T, Haydon C, Ropero S, Petrie K et al. 2005 Loss of acetylation at Lys 16 and trimethylation at Lys 20 of histone $\mathrm{H} 4$ is a common hallmark of human cancer. Nature Genetics 37 391-400. (doi:10.1038/ng1531)

Friedman OM, Mahapatra GN \& Stevenson R 1963 The methylation of deoxyribonucleosides by diazomethane. Biochimica et Biophysica Acta 68 144-146. (doi:10.1016/0926-6550(63)90422-5)

Frolich JC, Bloomgarden ZT, Oates JA, McGuigan JE \& Rabinowitz D 1978 The carcinoid flush. Provocation by pentagastrin and inhibition by somatostatin. New England Journal of Medicine 299 1055-1057. (doi:10.1056/NEJM197811092991908)

Fu S, Hu W, Iyer R, Kavanagh JJ, Coleman RL, Levenback CF, Sood AK, Wolf JK, Gershenson DM, Markman M et al. 2011 Phase 1b-2a study to reverse platinum resistance through use of a hypomethylating agent, azacitidine, in patients with platinum-resistant or platinumrefractory epithelial ovarian cancer. Cancer 117 1661-1669. (doi:10.1002/cncr.25701)

Geli J, Kiss N, Karimi M, Lee JJ, Backdahl M, Ekstrom TJ \& Larsson C 2008 Global and regional CpG methylation in pheochromocytomas and abdominal paragangliomas: association to malignant behavior. Clinical Cancer Research 14 2551-2559. (doi:10.1158/1078-0432.CCR-07-1867)
Greenblatt DY, Vaccaro AM, Jaskula-Sztul R, Ning L, Haymart M, Kunnimalaiyaan M \& Chen H 2007 Valproic acid activates notch-1 signaling and regulates the neuroendocrine phenotype in carcinoid cancer cells. Oncologist 12 942-951. (doi:10.1634/theoncologist. 12-8-942)

Greger V, Passarge E, Hopping W, Messmer E \& Horsthemke B 1989 Epigenetic changes may contribute to the formation and spontaneous regression of retinoblastoma. Human Genetics 83 155-158. (doi:10.1007/BF00286709)

Habbe N, Bert T \& Simon B 2007 Identification of methylation-associated gene expression in neuroendocrine pancreatic tumor cells. Pancreatology 7 352-359. (doi:10.1159/000107270)

Hamfjord J, Stangeland AM, Hughes T, Skrede ML, Tveit KM, Ikdahl T \& Kure EH 2012 Differential expression of miRNAs in colorectal cancer: comparison of paired tumor tissue and adjacent normal mucosa using high-throughput sequencing. PLOS ONE 7 e34150. (doi:10.1371/ journal.pone.0034150)

Heaphy CM, de Wilde RF, Jiao Y, Klein AP, Edil BH, Shi C, Bettegowda C, Rodriguez FJ, Eberhart CG, Hebbar S et al. 2011a Altered telomeres in tumors with ATRX and DAXX mutations. Science 333425. (doi:10.1126/science.1207313)

Heaphy CM, Subhawong AP, Hong SM, Goggins MG, Montgomery EA, Gabrielson E, Netto GJ, Epstein JI, Lotan TL, Westra WH et al. 2011b Prevalence of the alternative lengthening of telomeres telomere maintenance mechanism in human cancer subtypes. American Journal of Pathology 179 1608-1615. (doi:10.1016/j.ajpath.2011.06.018)

Hegi ME, Diserens AC, Gorlia T, Hamou MF, de Tribolet N, Weller M, Kros JM, Hainfellner JA, Mason W, Mariani L et al. 2005 MGMT gene silencing and benefit from temozolomide in glioblastoma. New England Journal of Medicine 352 997-1003. (doi:10.1056/NEJMoa043331)

Helmbold P, Lahtz C, Enk A, Herrmann-Trost P, Marsch W, Kutzner H \& Dammann RH 2009 Frequent occurrence of RASSF1A promoter hypermethylation and Merkel cell polyomavirus in Merkel cell carcinoma. Molecular Carcinogenesis 48 903-909. (doi:10.1002/mc.20540)

Herman JG, Latif F, Weng Y, Lerman MI, Zbar B, Liu S, Samid D, Duan DS, Gnarra JR, Linehan WM et al. 1994 Silencing of the VHL tumorsuppressor gene by DNA methylation in renal carcinoma. PNAS 91 9700-9704. (doi:10.1073/pnas.91.21.9700)

Herman JG, Merlo A, Mao L, Lapidus RG, Issa JP, Davidson NE, Sidransky D \& Baylin SB 1995 Inactivation of the CDKN2/p16/MTS1 gene is frequently associated with aberrant DNA methylation in all common human cancers. Cancer Research 55 4525-4530.

House MG, Herman JG, Guo MZ, Hooker CM, Schulick RD, Lillemoe KD, Cameron JL, Hruban RH, Maitra A \& Yeo CJ 2003 Aberrant hypermethylation of tumor suppressor genes in pancreatic endocrine neoplasms. Annals of Surgery 238 423-431 (discussion 431-422).

Jenuwein T \& Allis CD 2001 Translating the histone code. Science 293 1074-1080. (doi:10.1126/science.1063127)

Jiao Y, Shi C, Edil BH, de Wilde RF, Klimstra DS, Maitra A, Schulick RD, Tang LH, Wolfgang CL, Choti MA et al. 2011 DAXX/ATRX, MEN1, and mTOR pathway genes are frequently altered in pancreatic neuroendocrine tumors. Science 331 1199-1203. (doi:10.1126/science.1200609)

Jones PA \& Baylin SB 2002 The fundamental role of epigenetic events in cancer. Nature Reviews. Genetics 3 415-428. (doi:10.1038/nrg962)

Jones PA \& Martienssen R 2005 A blueprint for a Human Epigenome Project: the AACR Human Epigenome Workshop. Cancer Research 65 11241-11246. (doi:10.1158/0008-5472.CAN-05-3865)

Kaminskas E, Farrell A, Abraham S, Baird A, Hsieh LS, Lee SL, Leighton JK, Patel H, Rahman A, Sridhara R et al. 2005 Approval summary: azacitidine for treatment of myelodysplastic syndrome subtypes. Clinical Cancer Research 11 3604-3608. (doi:10.1158/ 1078-0432.CCR-04-2135)

Kiss NB, Geli J, Lundberg F, Avci C, Velazquez-Fernandez D, Hashemi J, Weber G, Hoog A, Ekstrom TJ, Backdahl M et al. 2008 Methylation of the p16INK4A promoter is associated with malignant behavior in 
abdominal extra-adrenal paragangliomas but not pheochromocytomas. Endocrine-Related Cancer 15 609-621. (doi:10.1677/ERC-07-0285)

Kiss NB, Muth A, Andreasson A, Juhlin CC, Geli J, Backdahl M, Hoog A, Wangberg B, Nilsson O, Ahlman H et al. 2013 Acquired hypermethylation of the P16INK4A promoter in abdominal paraganglioma: relation to adverse tumor phenotype and predisposing mutation. Endocrine-Related Cancer 20 65-78. (doi:10.1530/ERC-12-0267)

Krenning EP, Bakker WH, Breeman WA, Koper JW, Kooij PP, Ausema L, Lameris JS, Reubi JC \& Lamberts SW 1989 Localisation of endocrinerelated tumours with radioiodinated analogue of somatostatin. Lancet 1 242-244. (doi:10.1016/S0140-6736(89)91258-0)

Krenning EP, de Jong M, Kooij PP, Breeman WA, Bakker WH, de Herder WW, van Eijck CH, Kwekkeboom DJ, Jamar F, Pauwels S et al. 1999 Radiolabelled somatostatin analogue(s) for peptide receptor scintigraphy and radionuclide therapy. Annals of Oncology 10 (Suppl 2) S23-S29. (doi:10.1093/annonc/10.suppl_2.S23)

Kunnimalaiyaan M, Vaccaro AM, Ndiaye MA \& Chen H 2006 Overexpression of the NOTCH1 intracellular domain inhibits cell proliferation and alters the neuroendocrine phenotype of medullary thyroid cancer cells. Journal of Biological Chemistry 281 39819-39830. (doi:10.1074/jbc.M603578200)

Lagos-Quintana M, Rauhut R, Lendeckel W \& Tuschl T 2001 Identification of novel genes coding for small expressed RNAs. Science 294 853-858. (doi:10.1126/science.1064921)

LaRosa S, Marando A, Furlan D, Sahnane N \& Capella C 2012 Colorectal poorly differentiated neuroendocrine carcinomas and mixed adenoneuroendocrine carcinomas: insights into the diagnostic immunophenotype, assessment of methylation profile, and search for prognostic markers. American Journal of Surgical Pathology 36 601-611. (doi:10.1097/PAS.0b013e318242e21c)

Lassacher A, Heitzer E, Kerl H \& Wolf P 2008 p14ARF hypermethylation is common but INK4a-ARF locus or p53 mutations are rare in Merkel cell carcinoma. Journal of Investigative Dermatology 128 1788-1796. (doi:10.1038/sj.jid.5701256)

Lee S, Paulson KG, Murchison EP, Afanasiev OK, Alkan C, Leonard JH, Byrd DR, Hannon GJ \& Nghiem P 2011 Identification and validation of a novel mature microRNA encoded by the Merkel cell polyomavirus in human Merkel cell carcinomas. Journal of Clinical Virology 52 272-275. (doi:10.1016/j.jcv.2011.08.012)

Lee HW, Lee EH, Ha SY, Lee CH, Chang HK, Chang S, Kwon KY, Hwang IS, Roh MS \& Seo JW 2012 Altered expression of microRNA miR-21, miR-155, and let-7a and their roles in pulmonary neuroendocrine tumors. Pathology International 62 583-591. (doi:10.1111/ j.1440-1827.2012.02845.x)

Lembeck F 1954 Detection of 5-hydroxytryptamine in carcinoid metastases. Naunyn-Schmiedebergs Archiv fur experimentelle Pathologie und Pharmakologie 221 50-66.

Li F, Ye B, Hong L, Xu H \& Fishbein MC 2011 Epigenetic modifications of histone h4 in lung neuroendocrine tumors. Applied Immunohistochemistry \& Molecular Morphology 19 389-394. (doi:10.1097/ PAI.0b013e3182108e2e)

Li SC, Martinjn C, Essaghir A, Lloyd RV, Demoulin J, Oberg K \& Giandomenico V 2012 Role of microRNAs in small intestinal neuroendocrine tumours. Neuroendocrinology 96 1-72.

Lister R, O'Malley RC, Tonti-Filippini J, Gregory BD, Berry CC, Millar AH \& Ecker JR 2008 Highly integrated single-base resolution maps of the epigenome in Arabidopsis. Cell 133 523-536. (doi:10.1016/ j.cell.2008.03.029)

Liu L, Broaddus RR, Yao JC, Xie S, White JA, Wu TT, Hamilton SR \& Rashid A 2005 Epigenetic alterations in neuroendocrine tumors: methylation of RAS-association domain family 1, isoform A and p16 genes are associated with metastasis. Modern Pathology 18 $1632-1640$.

Liu R, Liao J, Yang M, Shi Y, Peng Y, Wang Y, Pan E, Guo W, Pu Y \& Yin L 2012 Circulating miR-155 expression in plasma: a potential biomarker for early diagnosis of esophageal cancer in humans. Journal of Toxicology and Environmental Health. Part A 75 1154-1162. (doi:10.1080/ 15287394.2012.699856)

Lu J, Getz G, Miska EA, Alvarez-Saavedra E, Lamb J, Peck D, Sweet-Cordero A, Ebert BL, Mak RH, Ferrando AA et al. 2005 MicroRNA expression profiles classify human cancers. Nature $\mathbf{4 3 5}$ 834-838. (doi:10.1038/ nature03702)

Lubomierski N, Kersting M, Bert T, Muench K, Wulbrand U, Schuermann M, Bartsch D \& Simon B 2001 Tumor suppressor genes in the 9 p21 gene cluster are selective targets of inactivation in neuroendocrine gastroenteropancreatic tumors. Cancer Research $\mathbf{6 1}$ 5905-5910.

Magerl C, Ellinger J, Braunschweig T, Kremmer E, Koch LK, Holler T, Buttner R, Luscher B \& Gutgemann I 2010 H3K4 dimethylation in hepatocellular carcinoma is rare compared with other hepatobiliary and gastrointestinal carcinomas and correlates with expression of the methylase Ash2 and the demethylase LSD1. Human Pathology $\mathbf{4 1}$ 181-189. (doi:10.1016/j.humpath.2009.08.007)

Malpeli G, Amato E, Dandrea M, Fumagalli C, Debattisti V, Boninsegna L, Pelosi G, Falconi M \& Scarpa A 2011 Methylation-associated down-regulation of RASSF1A and up-regulation of RASSF1C in pancreatic endocrine tumors. BMC Cancer 11 351. (doi:10.1186/14712407-11-351)

Mann BS, Johnson JR, Cohen MH, Justice R \& Pazdur R 2007 FDA approval summary: vorinostat for treatment of advanced primary cutaneous T-cell lymphoma. Oncologist 12 1247-1252. (doi:10.1634/theoncologist.12-10-1247)

Margetts CD, Astuti D, Gentle DC, Cooper WN, Cascon A, Catchpoole D, Robledo M, Neumann HP, Latif F \& Maher ER 2005 Epigenetic analysis of HIC1, CASP8, FLIP, TSP1, DCR1, DCR2, DR4, DR5, KvDMR1, H19 and preferential 11p15.5 maternal-allele loss in von Hippel-Lindau and sporadic phaeochromocytomas. Endocrine-Related Cancer 12 161-172. (doi:10.1677/erc.1.00865)

Margetts CD, Morris M, Astuti D, Gentle DC, Cascon A, McRonald FE, Catchpoole D, Robledo M, Neumann HP, Latif F et al. 2008 Evaluation of a functional epigenetic approach to identify promoter region methylation in phaeochromocytoma and neuroblastoma. Endocrine-Related Cancer 15 777-786. (doi:10.1677/ERC-08-0072)

Matei D, Fang F, Shen C, Schilder J, Arnold A, Zeng Y, Berry WA, Huang T \& Nephew KP 2012 Epigenetic resensitization to platinum in ovarian cancer. Cancer Research 72 2197-2205. (doi:10.1158/0008-5472.CAN11-3909)

Mei M, Deng D, Liu TH, Sang XT, Lu X, Xiang HD, Zhou J, Wu H, Yang Y, Chen J et al. 2009 Clinical implications of microsatellite instability and MLH1 gene inactivation in sporadic insulinomas. Journal of Clinical Endocrinology and Metabolism 94 3448-3457. (doi:10.1210/ jc.2009-0173)

Merlo A, Herman JG, Mao L, Lee DJ, Gabrielson E, Burger PC, Baylin SB \& Sidransky D $19955^{\prime}$ CpG island methylation is associated with transcriptional silencing of the tumour suppressor p16/CDKN2/MTS1 in human cancers. Nature Medicine 1 686-692. (doi:10.1038/ nm0795-686)

Meyer-Rochow GY, Jackson NE, Conaglen JV, Whittle DE, Kunnimalaiyaan M, Chen H, Westin G, Sandgren J, Stalberg P, Khanafshar E et al. 2010 MicroRNA profiling of benign and malignant pheochromocytomas identifies novel diagnostic and therapeutic targets. Endocrine-Related Cancer 17 835-846. (doi:10.1677/ERC-10-0142)

Modlin IM, Shapiro MD \& Kidd M 2004 Siegfried Oberndorfer: origins and perspectives of carcinoid tumors. Human Pathology 35 1440-1451. (doi:10.1016/j.humpath.2004.09.018)

Moertel CG, Hanley JA \& Johnson LA 1980 Streptozocin alone compared with streptozocin plus fluorouracil in the treatment of advanced isletcell carcinoma. New England Journal of Medicine 303 1189-1194. (doi:10.1056/NEJM198011203032101)

Mohammed TA, Holen KD, Jaskula-Sztul R, Mulkerin D, Lubner SJ, Schelman WR, Eickhoff J, Chen H \& Loconte NK 2011 A pilot phase II study of valproic acid for treatment of low-grade neuroendocrine 
carcinoma. Oncologist 16 835-843. (doi:10.1634/theoncologist. 2011-0031)

Muller CI, Ruter B, Koeffler HP \& Lubbert M 2006 DNA hypermethylation of myeloid cells, a novel therapeutic target in MDS and AML. Current Pharmaceutical Biotechnology 7 315-321. (doi:10.2174/138920106 778521523)

Muscarella P, Melvin WS, Fisher WE, Foor J, Ellison EC, Herman JG, Schirmer WJ, Hitchcock CL, DeYoung BR \& Weghorst CM 1998 Genetic alterations in gastrinomas and nonfunctioning pancreatic neuroendocrine tumors: an analysis of p16/MTS1 tumor suppressor gene inactivation. Cancer Research 58 237-240.

Oberg K, Funa K \& Alm G 1983 Effects of leukocyte interferon on clinical symptoms and hormone levels in patients with mid-gut carcinoid tumors and carcinoid syndrome. New England Journal of Medicine 309 129-133. (doi:10.1056/NEJM198307213090301)

O'Connor DT \& Deftos LJ 1986 Secretion of chromogranin A by peptideproducing endocrine neoplasms. New England Journal of Medicine $\mathbf{3 1 4}$ 1145-1151. (doi:10.1056/NEJM198605013141803)

Okano M, Xie S \& Li E 1998 a Cloning and characterization of a family of novel mammalian DNA (cytosine-5) methyltransferases. Nature Genetics 19 219-220. (doi:10.1038/890)

Okano M, Xie S \& Li E 1998 b Dnt2 is not required for de novo and maintenance methylation of viral DNA in embryonic stem cells. Nucleic Acids Research 26 2536-2540. (doi:10.1093/nar/26.11.2536)

Okano M, Bell DW, Haber DA \& Li E 1999 DNA methyltransferases Dnmt3a and Dnmt3b are essential for de novo methylation and mammalian development. Cell 99 247-257. (doi:10.1016/S0092-8674(00)81656-6)

Oki Y, Aoki E \& Issa JP 2007 Decitabine - bedside to bench. Critical Reviews in Oncology/Hematology 61 140-152. (doi:10.1016/j.critrevonc. 2006.07.010)

Ozata DM, Caramuta S, Velazquez-Fernandez D, Akcakaya P, Xie H, Hoog A, Zedenius J, Backdahl M, Larsson C \& Lui WO 2011 The role of microRNA deregulation in the pathogenesis of adrenocortical carcinoma. Endocrine-Related Cancer 18 643-655. (doi:10.1530/ERC11-0082)

Patterson EE, Holloway AK, Weng J, Fojo T \& Kebebew E 2011 MicroRNA profiling of adrenocortical tumors reveals miR-483 as a marker of malignancy. Cancer 117 1630-1639. (doi:10.1002/cncr.25724)

Patterson E, Webb R, Weisbrod A, Bian B, He M, Zhang L, Holloway AK, Krishna R, Nilubol N, Pacak K et al. 2012 The microRNA expression changes associated with malignancy and SDHB mutation in pheochromocytoma. Endocrine-Related Cancer 19 157-166. (doi:10.1530/ ERC-11-0308)

Pelosi G, Fumagalli C, Trubia M, Sonzogni A, Rekhtman N, Maisonneuve P, Galetta D, Spaggiari L, Veronesi G, Scarpa A et al. 2010 Dual role of RASSF1 as a tumor suppressor and an oncogene in neuroendocrine tumors of the lung. Anticancer Research 30 4269-4281.

Pernow B \& Waldenstrom J 1954 Paroxysmal flushing and other symptoms caused by 5-hydroxytryptamine and histamine in patients with malignant tumours. Lancet 267 951. (doi:10.1016/S0140-6736 (54)92559-3)

Pizzi S, Azzoni C, Bottarelli L, Campanini N, D'Adda T, Pasquali C, Rossi G, Rindi G \& Bordi C 2005 RASSF1A promoter methylation and 3p21.3 loss of heterozygosity are features of foregut, but not midgut and hindgut, malignant endocrine tumours. Journal of Pathology 206 409-416. (doi:10.1002/path.1784)

Radtke F \& Raj K 2003 The role of Notch in tumorigenesis: oncogene or tumour suppressor? Nature Reviews. Cancer 3 756-767. (doi:10.1038/ nrc1186)

Rahman MM, Qian ZR, Wang EL, Yoshimoto K, Nakasono M, Sultana R, Yoshida T, Hayashi T, Haba R, Ishida M et al. 2010 DNA methyltransferases $1,3 \mathrm{a}$, and $3 \mathrm{~b}$ overexpression and clinical significance in gastroenteropancreatic neuroendocrine tumors. Human Pathology 41 1069-1078. (doi:10.1016/j.humpath.2010.01.011)

Rajguru S, Lubner SJ, Mulkerin D, Schelman WR, Winterle N, Holen KD, Leverson G, Chen H \& LoConte NK 2012 A phase II study of the histone deacetylase inhibitor panobinostat (LBH589) in low-grade neuroendocrine tumors. ASCO Meeting Abstracts 30 e14554.

Raymond E, Dahan L, Raoul JL, Bang YJ, Borbath I, Lombard-Bohas C, Valle J, Metrakos P, Smith D, Vinik A et al. 2011 Sunitinib malate for the treatment of pancreatic neuroendocrine tumors. New England Journal of Medicine 364 501-513. (doi:10.1056/NEJMoa1003825)

Rechache NS, Wang Y, Stevenson HS, Killian JK, Edelman DC, Merino M, Zhang L, Nilubol N, Stratakis CA, Meltzer PS et al. 2012 DNA methylation profiling identifies global methylation differences and markers of adrenocortical tumors. Journal of Clinical Endocrinology and Metabolism 97 E1004-E1013. (doi:10.1210/jc.2011-3298)

Rinke A, Muller HH, Schade-Brittinger C, Klose KJ, Barth P, Wied M, Mayer C, Aminossadati B, Pape UF, Blaker M et al. 2009 Placebocontrolled, double-blind, prospective, randomized study on the effect of octreotide LAR in the control of tumor growth in patients with metastatic neuroendocrine midgut tumors: a report from the PROMID Study Group. Journal of Clinical Oncology 27 4656-4663. (doi:10.1200/ JCO.2009.22.8510)

Roldo C, Missiaglia E, Hagan JP, Falconi M, Capelli P, Bersani S, Calin GA, Volinia S, Liu CG, Scarpa A et al. 2006 MicroRNA expression abnormalities in pancreatic endocrine and acinar tumors are associated with distinctive pathologic features and clinical behavior. Journal of Clinical Oncology 24 4677-4684. (doi:10.1200/JCO.2005.05.5194)

Ruebel K, Leontovich AA, Stilling GA, Zhang S, Righi A, Jin L \& Lloyd RV 2010 MicroRNA expression in ileal carcinoid tumors: downregulation of microRNA-133a with tumor progression. Modern Pathology 23 367-375. (doi:10.1038/modpathol.2009.161)

Sakai T, Toguchida J, Ohtani N, Yandell DW, Rapaport JM \& Dryja TP 1991 Allele-specific hypermethylation of the retinoblastoma tumorsuppressor gene. American Journal of Human Genetics 48 880-888.

Schmitt AM, Schmid S, Rudolph T, Anlauf M, Prinz C, Kloppel G, Moch H, Heitz PU, Komminoth P \& Perren A 2009 VHL inactivation is an important pathway for the development of malignant sporadic pancreatic endocrine tumors. Endocrine-Related Cancer 16 1219-1227. (doi:10.1677/ERC-08-0297)

Schmitz KJ, Helwig J, Bertram S, Sheu SY, Suttorp AC, Seggewiss J, Willscher E, Walz MK, Worm K \& Schmid KW 2011 Differential expression of microRNA-675, microRNA-139-3p and microRNA-335 in benign and malignant adrenocortical tumours. Journal of Clinical Pathology 64 529-535. (doi:10.1136/jcp.2010.085621)

Schwartzentruber J, Korshunov A, Liu XY, Jones DT, Pfaff E, Jacob K, Sturm D, Fontebasso AM, Quang DA, Tonjes M et al. 2012 Driver mutations in histone $\mathrm{H} 3.3$ and chromatin remodelling genes in paediatric glioblastoma. Nature 482 226-231. (doi:10.1038/nature10833)

Seligson DB, Horvath S, Shi T, Yu H, Tze S, Grunstein M \& Kurdistani SK 2005 Global histone modification patterns predict risk of prostate cancer recurrence. Nature 435 1262-1266. (doi:10.1038/nature03672)

Serrano J, Goebel SU, Peghini PL, Lubensky IA, Gibril F \& Jensen RT 2000 Alterations in the p16INK4a/CDKN2A tumor suppressor gene in gastrinomas. Journal of Clinical Endocrinology and Metabolism $\mathbf{8 5}$ 4146-4156. (doi:10.1210/jc.85.11.4146)

Shah MH, Binkley P, Chan K, Xiao J, Arbogast D, Collamore M, Farra Y, Young D \& Grever M 2006 Cardiotoxicity of histone deacetylase inhibitor depsipeptide in patients with metastatic neuroendocrine tumors. Clinical Cancer Research 12 3997-4003. (doi:10.1158/10780432.CCR-05-2689)

Shivakumar L, Minna J, Sakamaki T, Pestell R \& White MA 2002 The RASSF1A tumor suppressor blocks cell cycle progression and inhibits cyclin D1 accumulation. Molecular and Cellular Biology 22 4309-4318. (doi:10.1128/MCB.22.12.4309-4318.2002)

Singh P, Soon PS, Feige JJ, Chabre O, Zhao JT, Cherradi N, Lalli E \& Sidhu SB 2012 Dysregulation of microRNAs in adrenocortical tumors. Molecular and Cellular Endocrinology 351 118-128. (doi:10.1016/j.mce. 2011.09.041)

Soon PS, Tacon LJ, Gill AJ, Bambach CP, Sywak MS, Campbell PR, Yeh MW, Wong SG, Clifton-Bligh RJ, Robinson BG et al. 2009 miR-195 and miR- 
483-5p identified as predictors of poor prognosis in adrenocortical cancer. Clinical Cancer Research 15 7684-7692. (doi:10.1158/10780432.CCR-09-1587)

Stricker I, Tzivras D, Nambiar S, Wulf J, Liffers ST, Vogt M, Verdoodt B, Tannapfel A \& Mirmohammadsadegh A 2012 Site- and grade-specific diversity of LINE1 methylation pattern in gastroenteropancreatic neuroendocrine tumours. Anticancer Research 32 3699-3706.

Suh I, Weng J, Fernandez-Ranvier G, Shen WT, Duh QY, Clark OH \& Kebebew E 2010 Antineoplastic effects of decitabine, an inhibitor of DNA promoter methylation, in adrenocortical carcinoma cells. Archives of Surgery 145 226-232. (doi:10.1001/archsurg.2009.292)

Tahiliani M, Koh KP, Shen Y, Pastor WA, Bandukwala H, Brudno Y, Agarwal S, Iyer LM, Liu DR, Aravind L et al. 2009 Conversion of 5-methylcytosine to 5-hydroxymethylcytosine in mammalian DNA by MLL partner TET1. Science 324 930-935. (doi:10.1126/science.1170116)

The American Association for Cancer Research Human Epigenome Task Force \& European Union NoE, Scientific Advisory Board 2008 Moving AHEAD with an international human epigenome project. Nature $\mathbf{4 5 4}$ 711-715. (doi:10.1038/454711a)

Tombol Z, Szabo PM, Molnar V, Wiener Z, Tolgyesi G, Horanyi J, Riesz P, Reismann P, Patocs A, Liko I et al. 2009 Integrative molecular bioinformatics study of human adrenocortical tumors: microRNA, tissue-specific target prediction, and pathway analysis. EndocrineRelated Cancer 16 895-906. (doi:10.1677/ERC-09-0096)

Tombol Z, Eder K, Kovacs A, Szabo PM, Kulka J, Liko I, Zalatnai A, Racz G, Toth M, Patocs A et al. 2010 MicroRNA expression profiling in benign (sporadic and hereditary) and recurring adrenal pheochromocytomas. Modern Pathology 23 1583-1595. (doi:10.1038/modpathol.2010.164)

Toyota M, Ahuja N, Ohe-Toyota M, Herman JG, Baylin SB \& Issa JP 1999 CpG island methylator phenotype in colorectal cancer. PNAS 96 8681-8686. (doi:10.1073/pnas.96.15.8681)

Ulaner GA, Huang HY, Otero J, Zhao Z, Ben-Porat L, Satagopan JM, Gorlick R, Meyers P, Healey JH, Huvos AG et al. 2003 Absence of a telomere maintenance mechanism as a favorable prognostic factor in patients with osteosarcoma. Cancer Research 63 1759-1763.

Waddington CH 1957 The Strategy of the Genes: a Discussion of Some Aspects of Theoretical Biology. London: Allen, Unwin.
Wang T, Lv M, Shen S, Zhou S, Wang P, Chen Y, Liu B, Yu L \& Hou Y 2012 Cell-free microRNA expression profiles in malignant effusion associated with patient survival in non-small cell lung cancer. PLOS ONE 7 e43268. (doi:10.1371/journal.pone.0043268)

Warneboldt J, Haller F, Horstmann O, Danner BC, Fuzesi L, Doenecke D \& Happel N 2008 Histone H1x is highly expressed in human neuroendocrine cells and tumours. BMC Cancer 8 388. (doi:10.1186/ 1471-2407-8-388)

Wild A, Ramaswamy A, Langer P, Celik I, Fendrich V, Chaloupka B, Simon B \& Bartsch DK 2003 Frequent methylation-associated silencing of the tissue inhibitor of metalloproteinase- 3 gene in pancreatic endocrine tumors. Journal of Clinical Endocrinology and Metabolism 88 1367-1373. (doi:10.1210/jc.2002-021027)

de Wilde RF, Heaphy CM, Maitra A, Meeker AK, Edil BH, Wolfgang CL, Ellison TA, Schulick RD, Molenaar IQ, Valk GD et al. 2012 Loss of ATRX or DAXX expression and concomitant acquisition of the alternative lengthening of telomeres phenotype are late events in a small subset of MEN-1 syndrome pancreatic neuroendocrine tumors. Modern Pathology 25 1033-1039.

Yao JC, Shah MH, Ito T, Bohas CL, Wolin EM, Van Cutsem E, Hobday TJ, Okusaka T, Capdevila J, de Vries EG et al. 2011 Everolimus for advanced pancreatic neuroendocrine tumors. New England Journal of Medicine 364 514-523. (doi:10.1056/NEJMoa1009290)

Yashiro T, Fulton N, Hara H, Yasuda K, Montag A, Yashiro N, Straus F, II, Ito K, Aiyoshi Y \& Kaplan EL 1993 Comparison of mutations of ras oncogene in human pancreatic exocrine and endocrine tumors. Surgery 114 758-763 (discussion 763-754).

Yoshimoto K, Iwahana H, Fukuda A, Sano T, Saito S \& Itakura M 1992 Role of p53 mutations in endocrine tumorigenesis: mutation detection by polymerase chain reaction-single strand conformation polymorphism. Cancer Research 52 5061-5064.

Zhang HY, Rumilla KM, Jin L, Nakamura N, Stilling GA, Ruebel KH, Hobday TJ, Erlichman C, Erickson LA \& Lloyd RV 2006 Association of DNA methylation and epigenetic inactivation of RASSF1A and $\beta$-catenin with metastasis in small bowel carcinoid tumors. Endocrine 30 299-306. (doi:10.1007/s12020-006-0008-1)

Received in final form 4 February 2013

Accepted 18 February 2013

Made available online as an Accepted Preprint

21 February 2013 http://erc.endocrinology-journals.org DOI: 10.1530/ERC-12-0338
(C) 2013 Society for Endocrinology Printed in Great Britain 